\title{
Article \\ International Relations by Proxy? The Kremlin and the Russian Orthodox Church
}

\author{
George Soroka
}

check for updates

Citation: Soroka, George. 2022. International Relations by Proxy? The Kremlin and the Russian Orthodox Church. Religions 13: 208. https://doi.org/10.3390/ rel13030208

Academic Editors: Jeffrey Haynes and John Jillions

Received: 28 November 2021 Accepted: 10 February 2022 Published: 1 March 2022

Publisher's Note: MDPI stays neutral with regard to jurisdictional claims in published maps and institutional affiliations.

Copyright: (c) 2022 by the author. Licensee MDPI, Basel, Switzerland. This article is an open access article distributed under the terms and conditions of the Creative Commons Attribution (CC BY) license (https:/ / creativecommons.org/licenses/by/ $4.0 /)$.
Department of Government, Harvard University, Cambridge, MA 02138, USA; soroka@fas.harvard.edu

\begin{abstract}
Russian officials and the Moscow Patriarchate have worked together in recent years to promote a socially conservative policy agenda, both domestically and beyond the Russian Federation's borders. Examining official documents and the statements of key leaders, this article evaluates the development and nature of contemporary church-state relations as they pertain to international relations. The picture that emerges is one of pragmatic partnering, with the state increasingly inclining towards normative positions long espoused by the Church in an effort to shift its foreign policy in a direction that stresses civilizational differentiation and positions Russia as the protector of Christians and "traditional values" around the globe. Underlying this shift in orientation on the part of the Kremlin is a neorealist perspective (though one increasingly expressed through ideational rhetoric) that envisions Russia as not just having a privileged regional sphere of influence but becoming a major player in a polycentric world. As a means of legitimating these objectives, the Church has proven an ideal partner; however, it would be a mistake to simply regard the latter institution as an arm of the state, given that it has its own objectives and motivations relative to the wider world, and these at times conflict with those of the Kremlin.
\end{abstract}

Keywords: Russian Orthodox; church; Moscow; Kremlin; international relations; Russia

The barbarians did not dare leave an enslaved Rus' at their rear, and returned to their Eastern steppes. Christian enlightenment was saved by a ravaged and dying Russia. ${ }^{1}$

\section{Introduction}

The Russian Orthodox Church (ROC) has often been depicted by Western commentators as little more than a handmaiden of the state. In this regard, it is not unusual among the national Orthodox Churches, against which charges of being overly subordinate to secular authority have long been levelled. Samuel Huntington, in his The Clash of Civilizations and the Remaking of the World Order (a volume that enjoys great popularity in Russia) went so far as to aver that "in Orthodoxy, God is Caesar's junior partner" (Huntington 1996, p. 70). However, the truth is more complicated than can be captured in an aphorism, no matter how pithy it may be. Historically, the ROC has both challenged-as was the case under the $17^{\text {th }}$-century reformer Patriarch Nikon, who headed the Church from 1652 to 1666 -and been subjugated by the Russian state. Certainly from the time of Tsar Peter I, when the Patriarchate (the ROC's highest office) was abolished by imperial decree, to 1917, when it was reinstated, institutional arrangements between the Church and the ruling Romanov dynasty assumed more than a whiff of caesaropapism. Furthermore, although the ROC was at times heavily persecuted in the USSR, ${ }^{2}$ it was also utilized instrumentally by the Soviet authorities, as when Stalin relaxed restrictions on its functioning during World War II to rally patriotic sentiment and boost the populace's morale, reopening parishes and allowing Sergii (Stragorodskii) to be elected Patriarch in $1943 .^{3}$ The Church, however, paid a high price for this rapprochement, with the ROC coming to be extensively infiltrated by the regime's security organs during communist rule. ${ }^{4}$ Not only did this affect its internal affairs, but it also enabled the ROC to be utilized as a propaganda tool to improve the standing of the Soviet Union on the world stage through such activities as its participation in the 
World Council of Churches (WCC) and the international peace and nuclear disarmament movements (Armes 1992). ${ }^{5}$

Since the collapse of the USSR in 1991, church-state relations have become more convoluted. On the one hand, the ROC gained a level of independence from governmental control the likes of which it had never previously experienced. On the other hand, particularly after Kirill (Gundiaev) was elected Patriarch in 2009, the ROC and Kremlin have come to cooperate closely on a number of projects, high-level secular and ecclesial figures making common cause in a very public manner. This trend only accelerated after Vladimir Putin returned for a third presidential term in 2012. The synergistic effects of such partnering are today widely apparent in Russia, but they are especially evident in the conservative and moralizing rhetoric that has come to characterize how the Kremlin discusses its goals and priorities in the international relations arena.

This is not to imply that the ROC has been co-opted as an arm of the post-Soviet state, nor is it to naively suggest that the burgeoning of overt manifestations of Orthodoxy in political and military circles reflects a commensurate increase in sincere religious belief among Russian elites (though for some it genuinely may). ${ }^{6}$ In reality, the contemporary political visibility of the ROC is predicated on its usefulness in achieving concrete policy goals that are of interest to the state, the current modus vivendi having developed over the course of the last decade or so, a period that witnessed a strengthening alignment of interests between the ROC and various governmental structures. What is intriguing about this arrangement is that, in making the discursive shift to a foreign policy agenda that stresses Russia's role as a defender of "traditional values" and non-Western/illiberal worldviews around the globe, the Kremlin has inclined towards positions that have long been championed by the ROC, which speaks to the perceived symbolic capital and societal legitimacy of the Orthodox Church in contemporary Russia.

The first part of this article sets the context for subsequent inquiry by delimiting the scope of the research and highlighting the history of church-state relations. Second, the ROC's political stances and initiatives are examined as these extend beyond the Russian Federation's geopolitical borders. Third, Moscow's foreign policy aims are analyzed, focusing primarily on the post-2012 period. In the latter two instances, this is accomplished by drawing on surveys of official documents and media interviews with both Church hierarchs and state representatives. The fourth section discusses how the external policy preferences of the ROC and the Kremlin overlap with, as well as deviate from, one another. Finally, the conclusion draws out the broader implications of this study and suggests avenues for further research.

\section{Church-State Relations in Russia}

Ethnic nations, wherein belonging is assumed to stem from consanguineous descent and typically involves sharing common cultural, linguistic, historical, and religious repertoires, have long conflated the sacred with the profane. Arguably, all such entities have at some moment in time exhibited a self-perception of themselves as extraordinary, favored by divine grace and perhaps even imbued with a messianic mission. Among European nation-states, this is a palpable part of their socio-political story. Leaders sought the blessing of the Church before waging war, publics fasted and prayed when pestilence visited the land, and more than a handful of saints were canonized because they were believed to be pious and wise rulers while alive. In this regard, the Russian historical experience is little different from that of France or Holland.

Nonetheless, when it comes to adjudicating the legacies of religion's interaction with secular power, there are ways in which Russia is meaningfully distinguished from its neighbors, particularly those in Western Europe. Critically, the modern Russian state traces its roots back to the medieval principality of Kyivan Rus', a patrimony that it shares with Belarus and Ukraine. ${ }^{7}$ The Baptism of Rus' in 988 CE, when Grand Prince Vladimir imposed an eastern form of Christianity on his subjects (in the process sealing a dynastic marriage with Anna Porphyrogenita, daughter of the Byzantine Emperor Romanos II), 
permanently linked the political development of this proto-state and its eventual offshoots with Orthodoxy. ${ }^{8}$ The ROC is consequently a singular actor, as it can credibly claim not only a thousand-plus years of continuous history but also an institutional pedigree that predates even the establishment of a distinctive Russian ethnos.

In the intervening centuries, the Church functioned as a crucial locus of national identity formation, defending the state and preserving the culture of Rus' (and later the Russian Empire) against external threats running the gamut from Mongols and Teutonic Knights to Swedes and Poles. Indicative of this, Russia has a well-attested tradition of canonizing military heroes and political luminaries. These range from such revered medieval nobles as Aleksandr Nevskii and Dmitrii Donskoi to those who were more recently sainted, including Admiral Fedor Ushakov, the illustrious $18^{\text {th }}$-century naval commander (canonized 2001), and the last Romanov Tsar, Nicholas II, and his family (canonized 2000). ${ }^{9}$ The art and architecture of the ROC likewise reflects this linkage between the political and religious, whether it be the nearly four-meter-wide Blessed Be the Host of the Heavenly Tsar (also known as The Church Militant), an iconographic masterpiece that commemorates Ivan IV's 1552 conquest of Kazan, or Moscow's Cathedral of Christ the Savior, erected in the 19th century to give glory to God for the defeat of Napoleon's armies. ${ }^{10}$ More recently, we witnessed this same proclivity to connect martial themes to Orthodoxy in the construction of the Main Cathedral of the Russian Armed Forces, which was completed on 9 May 2020. ${ }^{11}$ Located on the outskirts of Russia's capital, this imposing structure, which features an atypical dark-green exterior reminiscent of military uniforms and hardware, is dedicated to the 75th anniversary of the Red Army's victory in World War II (as well as all Russian soldiers who served in previous conflicts). ${ }^{12}$

The involvement of imperial, and later national, rulers in ecclesial affairs (and vice versa) has a long and storied tradition in Christendom: The Edict of Thessalonica in $380 \mathrm{CE}$ officially made Christianity the religion of the Roman Empire, but it had already previously been adopted by monarchs in what are now Armenia, Ethiopia, and Georgia. At the same time, there is an inherent tension between the universalistic message of Christianity and the close identification many churches and denominations have with specific peoples. Painfully aware of this due to its multiple centers of ecclesial authority, Eastern Orthodoxy regards phyletism, or the privileging of ethno-nationalism over Christian unity, to be a heresy. As the current Patriarch of Moscow and all Rus'-note the geographic reach of the title, which spans across political boundaries to encompass what are today the sovereign states of Belarus, Russia, and Ukraine-put it shortly after his investiture, the "Russian Orthodox Church is not the Church of the Russian Federation," observing that there are more non-Russian than Russian bishops in its ranks (Interv'iu Sviateishego Patriarkha Kirilla 2009). ${ }^{13}$ Indeed, the ROC's claimed canonical jurisdiction extends well beyond the present-day borders of Russia and even the footprint of the former Tsarist empire and Soviet Union, encompassing religious bodies abroad directly administered by Moscow, various exarchates, and autonomous (internally self-governing) national churches-including such far-flung entities as the Orthodox Church of Japan-that nonetheless retain symbolic as well as certain practical connections to the "mother" Church. (This latter category includes the Ukrainian Orthodox Church-Moscow Patriarchate [UOC-MP]). Such cross-border relationships complicate the ties of the ROC to the Russian state.

Despite a rancorous and fraught history of church-state relations during the Soviet period, when the ROC endured successive waves of persecution and exploitation set against an ideological backdrop of state-sponsored atheism, relations between the ROC and Kremlin in the post-communist period have largely been cordial, with growing cooperation evinced in recent years. Indeed, today these two entities exhibit a high degree of symbiosis. This is partly a result of precedent and theology, the normative implications of the Byzantine principle of symphonia, or the harmonious and complementary co-existence of religious and secular authorities, never having fully been forgotten or abandoned. ${ }^{14}$ At the same time, it is also driven by more strategic and instrumental considerations; there is little doubt that 
the unique standing of the ROC in Russian society has been exploited by the regime to bolster its legitimacy, both at home and abroad. ${ }^{15}$

Nonetheless, the present-day ROC is neither an established church nor a department of the Russian state. It therefore does not occupy the same institutional position that England's Anglican Church or Denmark's Folkekirken does, even though it de facto enjoys a privileged socio-political position that is clearly in tension with article 14.1 of the 1993 Constitution, which defines the Russian Federation as a secular polity. ${ }^{16}$ However, despite not being an official state church, the ROC wields considerably more influence in Russia's domestic as well as foreign affairs than the formally established churches of such countries as England and Denmark could ever hope to in this day and age.

The ROC's influence did not emerge fully formed from the Soviet Union's collapse; relations between church and state in Russia have intensified over time as a result of political expediency and the agency of leading figures on both sides. Putin, for his part, was much less amenable to giving the Church what it wanted during his first two terms in office, despite identifying with Orthodoxy more overtly than his predecessor, Boris Yeltsin, ever had. ${ }^{17}$ As a result, while the ROC held a prominent position in Russian society throughout the 1990s and 2000s, it was a marginal political actor during this period (Soroka 2016; Papkova 2011, pp. 699-70). ${ }^{18}$ This situation only began to change in the second half of Dmitrii Medvedev's interregnum, when the Kremlin pivoted in a more socially conservative direction; exemplifying this is the stress the regime started to place on assuring that Russian youth were given a "patriotic" education and upbringing (Kratochvil and Shakhanova 2020). (Notably, this occurred after the death of Patriarch Aleksii [Ridiger] in December 2008). Still, it took Putin returning for a third presidential term in 2012 to solidify the ROC's political salience as a moral force for Russia's regeneration. ${ }^{19}$ That year augured what Andrei Tsygankov characterizes as a "civilizational turn" in the Kremlin's worldview (Tsygankov 2019, p. 232). ${ }^{20}$ Galvanized by the Bolotnaia Square protests that broke out in late 2011 after allegations of electoral irregularities, ${ }^{21}$ this shift accelerated in response to the 2013-2014 Maidan protests and the subsequent imposition of Western sanctions due to Moscow's annexation of Crimea and support for the separatist rebels in Ukraine's Donbas region. ${ }^{22}$ This new foreign policy direction was palpably manifest during Putin's speech at the 2013 Valdai Discussion Club, where he focused on the need to inculcate a strong national identity for strategic reasons, promoting the idea that it was necessary to preserve Russia's identity and the pillars on which it rests in order for the country to remain a significant power in a rapidly evolving and increasingly competitive global system (Zasedanie mezhdunarodnogo diskussionnogo kluba 2013). As a result, the Russian state has meaningfully converged on the Church's position with regard to social matters ${ }^{23}$ allowing the ROC to achieve more of its desired policy goals in the span of a few years than it had during the prior two post-communist decades.

However, while in a worldly sense the Kremlin is exponentially more powerful than the ROC, and some of the latter's hierarchs-particularly Patriarch Kirill—at times display a fealty bordering on obeisance towards Russia's secular leadership, the Church remains a multi-faceted and heterogenous organism whose political motivations and resultant preferences do not always align with those of Moscow (Soroka 2018a; Soroka 2016; Torbakov 2014, pp. 161-68). As a result, examining the ROC requires that we carefully delineate the requisite level of analysis, which necessitates differentiating between: (1) the ecclesiastical institution versus individuals who identity as Orthodox Christians; ${ }^{24}(2)$ individuals who profess true faith/belief versus those who treat Orthodoxy as a signifier of socio-cultural belonging; and (3) Orthodoxy as a private versus public identity. ${ }^{25}$ Below, the focus is specifically on elucidating the outward-facing relationship that exists between the Moscow Patriarchate (MP) and the contemporary Russian state, as well as between their respective leaders. This is not to imply that official documents and pronouncements made by political and Church figures should be uncritically accepted as motivating behavior. Putin's selfconscious turn toward espousing social conservativism as state policy may be understood 
as a highly instrumental move (Shekhovtsov 2018, pp. 79-91); ${ }^{26}$ the same argument may be made regarding the ROC's more overt embrace of the Kremlin following Kirill's enthronement. However, analyzing such materials is important in its own right, as they indicate what leaders desire to convey to publics concerning their actions.

\section{The ROC's Goals beyond Russia}

The ROC can hardly avoid participating in cross-border affairs given that the Church's canonical jurisdiction, along with its attendant political and economic interests, extend well beyond the contemporary boundaries of the Russian Federation. ${ }^{27}$ Assessed below are the priorities and preferences of the ROC in this realm, as well as the spatial and institutional modes of their accomplishment.

Practically, the ROC's concerns abroad revolve around shepherding its geographically dispersed and multi-national flock, maintaining/increasing its influence in the Orthodox world, regaining control over ecclesial properties that were lost as a result of the Bolshevik's victory in the Russian Civil War (1917-1923), and protecting persecuted Christians in regions of the world prone to sectarian violence, notably the Middle East and North Africa (MENA). In a broader ideational sense, the aims of the ROC center on upholding conservative religious and societal values in the face of what Church officials take to be their increasing irrelevance to (or even outright rejection by) the modern world and countering the homogenizing thrust of Western consumerist culture, along with its associated liberalism. The latter is viewed as being particularly pernicious due to what the Church regards as its active promotion of atomistic individualism and militant secularism, which it understands as detrimental to the collective societal good. ${ }^{28}$ These are not by any means new positions for the ROC; the current patriarch's predecessor, Aleksii, was already claiming two decades ago that the West was to blame for the moral degradation of Russia, asserting that "a well-planned, bloodless war is being waged against our nation, with the aim of destroying it" (Patriarkh Aleksii II 2000). Similarly, Kirill was propounding the supposed diametrical opposition of liberalism and Christianity well before he became patriarch. ${ }^{29}$ What has changed in recent years is that the Kremlin has become much more active in aiding the ROC to achieve these goals.

It is worth reiterating and amplifying the shift in the ROC's position regarding working with state officials that took place after Patriarch Aleksii died in December 2008. Under Aleksii's leadership, the post-communist Church had largely (though not entirely) sought to keep its distance from politics, particularly when it came to international relations. This changed markedly after Kirill assumed the Patriarchal Throne in February 2009. ${ }^{30}$ Whereas Aleksii had "persistently insisted that the Church and state must remain separate from each other" (Papkova 2011, p. 668), his successor quickly demonstrated a willingness to cooperate with Russian officials in order to pursue the ROC's interests. ${ }^{31}$

The seminal document dealing with the Church's view of its place in society, and its relationship to the state, is the Bases of the Social Concept of the Russian Orthodox Church (Osnovy sotsial'noi kontsepstii 2000), with key points related to the ROC's position on human rights emphasized and elaborated in the subsequent Declaration on the Rights and Dignity of Man of the 10th All-World Russian People's Council (Deklaratsiia o pravakh i dostoinstve cheloveka 2006) and the Fundamentals of the Russian Orthodox Church's Teaching on Dignity, Freedom, and Human Rights (Osnovy ucheniia Russkoi Pravoslavnoi Tserkvi 2008).

Prominent themes in the Social Concept that are discussed in a positive light include patriotism, traditional values, and multi-ethnic states. War and its justifications are also addressed, the focus being on a Christian's duties and obligations to homeland and nation (article VIII stresses that while war is "evil" and "undesirable" from the Church's perspective, it is nevertheless sometimes unavoidable). Meanwhile, themes that receive a negative treatment include secularization and globalization, with the ROC vehemently rejecting what it views as the West's attempts at cultural homogenization and reacting skeptically to the accompaniments of the latter, including the rise of international organizations. ${ }^{32}$ The alleged materialism of Western culture, which is juxtaposed against Christian spiritual and 
moral values and the need to preserve them, is accorded particular opprobrium. ${ }^{33}$ In this narrative, the European Union (EU) is depicted as hedonistic and enervated, having lost its ethical compass when it abandoned Christianity, within which Europe's civilization is inalterably rooted. ${ }^{34}$

Regarding cooperation between church and state, the Social Concept lists 16 possible arenas (III.8). Most are domestically oriented, but one specifically applies to the field of international relations: "peacemaking and promoting mutual understanding and cooperation among people, nations and states." (Article VIII.5 therefore states that the Church seeks to influence those in power to "carry out peacekeeping services both on a national and international scale.") Conversely, article III.8 also delineates activities in which clergy and church bodies cannot cooperate with the state, the most pertinent being in the conduct of a civil war or an offensive external conflict.

The treatment of warfare is especially interesting. The ROC calls on believers to protect their native soil if it is threatened, even at the cost of their lives (II.2). In this manner, it overtly links political violence to patriotism and support for co-ethnics, with the Social Concept observing that (II.3):

The Orthodox Christian is called to love his fatherland, which has a territorial dimension, and his brothers by blood who live everywhere in the world. This love is one of the ways of fulfilling God's commandment to love one's neighbor, which includes love of one's family, fellow-tribesmen, and fellow-citizens.

However, as Kirill elaborated shortly after becoming patriarch, patriotism and affection towards compatriots (a term synonymous with Russians and Russian speakers) are not to be conflated with nationalism but rather tempered by Christian universalism. According to him, this universalism provides "such a powerful moral motivation" that a believer's "loyalty to his state is always balanced by what we can term common human values, but not in the liberal, but rather Christian, sense" (Interv'iu Sviateishego Patriarkha Kirilla 2009).

Another prominent theme evinced in the Social Concept references the religious basis and moral dimension of foreign affairs, with this document noting that "[ $t]$ he development of high-minded legal norms in international relations would have been impossible" without Christianity (VIII.3). Consequently, Orthodox Christians should "strive for the creation" of relationships that will be "maximally beneficial for, and satisfy the legitimate interests of, their own people, neighboring nations, and the entire human family" (XVI.1) ${ }^{35}$

The Social Concept also expresses negative sentiments toward mono-ethnic states, the establishment of which it regards as constituting "the main reason for the bloody interethnic conflicts that shook Eastern Europe" (XVI.1). However, while this text acknowledges that monarchy was the traditional form of Biblical rule (III.7), the ROC effectively declares itself neutral as to the form of government a state should espouse. Nonetheless, the implicit worldview articulated here is imperial, with a sense of longing and loss expressed for the Soviet Union/Russian Empire (XVI.1):

The Church grieves when, in the division of a multiethnic state, a historical comm-unity of people is destroyed, their rights are violated, and suffering enters their life.

The division of a multinational state can be justified only if one of the peoples is clearly oppressed or the majority of a country do not exhibit a definite will to pre-serve unity.

Similarly, the Social Concept expresses a wariness of globalization predicated on the perceived threat that this phenomenon poses to the retention of a country's distinctive identity, which includes its spiritual and cultural underpinnings as well as the ability to defend its "legitimate interests" (such as territorial integrity) and "ensure the equality of sovereign states" (XVI.2). Economic injustices associated with an increasingly interconnected world are also highlighted (XVI.3). This document likewise criticizes the spread of the secularization paradigm and maintains that the Church "seeks recognition of the 
legitimacy of the religious worldview" to influence governmental behavior, international law and international organizations (XVI.4).

A number of these concepts are picked up and elaborated in the 2006 and 2008 texts. Putting the matter starkly, the Declaration on the Rights and Dignity of Man begins by observing that "the world is undergoing a decisive moment in history, it faces the threat of a conflict between civilizations that have different understandings of man and his purpose." The ROC believes individuals do possess inherent rights, but for the Church this universality applies not to human rights as such but rather to the moral foundations that undergird them, which are shared "without regard as to culture, nationality, or life circumstances." These rights, therefore, are viewed in a relational sense; their purpose is to aid in the realization of each individual's human dignity by encouraging him or her to make proper moral choices, as the "most important goal in the life of a person" should be to avoid sin and gain life everlasting. Divorcing human rights from morality is consequently regarded as a "profanation" of the former by the ROC. Moreover, the Church views "[t]he 'invention' of such 'rights' that legitimize behavior condemned by traditional morality and all historical religions" as being dangerous to society. Consequently, while the text concludes with a pledge to work with the state and "all well-meaning forces" to safeguard human rights, the notion of what must be protected differs dramatically from how these rights are generally understood in the Western world (Deklaratsiia o pravakh i dostoinstve cheloveka 2006).

The Fundamentals of the Russian Orthodox Church's Teaching continues this discussion, challenging the notion that human rights constitute an end unto themselves and maintaining that "in referencing the protection of these rights, in practice there are often achieved views that at their core diverge from Christian teaching." In particular, in this document the ROC expresses its concern that unreservedly defending an individual's freedom to choose how to live divorces the conception of rights from "the moral dimension of life and freedom from $\sin ^{\prime \prime}$ (II.2). Neither human rights nor morality are viewed subjectively; instead, the Church believes that there exists an objectively discernible and ontologically immanent truth (moreover, this is Truth-as-proper-noun, the totality of which only Orthodox Christianity deems itself to possess). "Individual human rights," as a result, "cannot be put into opposition to the values and interests of the Fatherland, society, and family" (III.5). As such, these rights are by their very nature circumscribed. Intriguingly, however, there is also present a suggestion that they are at least partly context dependent, as there is "no universal classification of rights and freedoms in the world" (IV.1).${ }^{36}$ It is unsurprising, therefore, that the ROC believes one civilization should not impose it beliefs and way of life on another, and that the protection of rights should not be made to serve the political goals of specific states (III.4). Although this is a normative orientation, the Church also pragmatically notes in article III.4 that attempts to respect rights and improve social and economic relations, as well as the institutions that govern them, "will not meet with true success if the spiritual and cultural traditions of countries and peoples are ignored" (Osnovy ucheniia Russkoi Pravoslavnoi Tserkvi 2008).

This document, like the preceding one, emphasizes that living in sin not only harms the sinner, but likewise "harms other people and the surrounding world" (I.4). For this reason, society has an interest in regulating the behavior of the individual. The freedom to do what one desires "is not an absolute and ultimate value" (II.1) but rather a value that exists in a relationship of obligation to both God and fellow humans. Viewed from this perspective, a fundamental weakness of the West's understanding of human rights is that, in supporting freedom of choice, it pays inadequate attention to moral questions (II.2). The text also raises the point that, for many societies, "it is not so much secularized standards of human rights" but rather "religious creeds and traditions that have the highest authority in public life and interpersonal relations" (III.2). Echoing the 2006 text, it likewise expresses an interest in protecting "human rights and dignity" by working "together with the state and societal forces" (V.3) and calls upon Christians to "take ethically guided social action" (V.4). 


\subsection{The ROC's Geographic Representation}

There are three distinct spatial arenas of interest to the Church, across which it exhibits successively diminishing levels of influence. Heuristically, we may conceptualize these as imperfectly formed spheres nested one within the other (rather akin to a stacking matreshka doll) that emanate outward from the geographic locus of the ROC. Located within the first of these is "Holy Rus'," or what is sometimes referred to as "Holy Russia" (Sviataia Rus' or Sviataia Rossiia, respectively). These are the lands that accepted Christianity with Grand Prince Vladimir's baptism, namely the present-day states of Belarus, Russia, and Ukraine, although the concept is occasionally stretched to include Kazakhstan and Moldova. Radiating outward, the next sphere consists of the "Orthodox neighborhood," the gradations of which encompass not only those Eastern Christian Slavic states (i.e., Bulgaria, Montenegro, Serbia) with which Russia shares much in common culturally, historically, and linguistically, but also extend to include more heterodox polities that feature large Russian diasporas (e.g., Latvia, Estonia), ${ }^{37}$ as well as non-Slavic redoubts of Orthodoxy. ${ }^{38}$ The ties exhibited to the ROC in the latter instance are weaker than in the preceding two but they are still present. This is the case for Orthodox-majority states such as Greece and Romania, ${ }^{39}$ as well as for polities located in the MENA region that were at one time anthropologically important for the Christian East (e.g., Jordan, Syria). Finally, the outermost sphere encompasses the "far abroad," referring to those segments of the globe that have never been part of the Orthodox world and that today do not feature sizeable Russian diasporas but where there nevertheless are found displaced eastern Slavs and their descendants, along with ideological fellow travelers attracted to the conservative theological and social values of the ROC. These boundaries are not neatly delineated in a relational sense, given their defining features are not deterministically correlated to physical spaces. On average, however, the further one moves away from Russia in any direction, the lower the socio-cultural and political salience that the ROC enjoys.

With respect to the innermost arena, within the MP there is evinced significant conflation between its religious, cultural, historical, and linguistic attributes. Indeed, for Kirill the concept of "Holy Russia" and its secular analogue of the "Russian world" (Russkii mir) have long been virtual synonyms, his use of them dependent on the audience he was addressing (Suslov 2018, p. 345). (However, recently the patriarch has noticeably shied away from employing the term "Russian world" in his public speeches. $)^{40}$ According to Kirill, the "Russian world is based on the Orthodox faith, which we found in the common Kievan baptismal font," but it also encompasses a common experiential background, along with similar views on societal development (Vystuplenie Sviateishego Patriarkha 2009). At the same time, this conceptual entity is not equivalent to the Russian Federation or even the historical Russian Empire. Rather, it constitutes "a special civilization" that encompasses Russians, Ukrainians, and Belarusians, as well as "people who are not part of the Slavic world at all, but who have accepted the cultural and spiritual composition of this world as their own" (Sviateishii Patriarkh Kirill 2014). ${ }^{41}$

This idea of protecting a unique civilization is repeatedly encountered in the statements of the patriarch and the ROC. (As Mikhail Suslov notes, the Church "actively presents itself as the sole integrative force in the space of the former Soviet Union" [2015, p. 44]). Speaking before the third Assembly of the Russian World, Kirill stated that "representatives of diverse cultures" can either yield to powerful global trends and "dissolve in them" or retain their independence and play a role in formulating a new world order (Vystuplenie Sviateishego Patriarkha 2009). Five years later, he observed that the "peacefulness" of the Eastern Slavs derives from their distinctive religious values, and that without these, "there will be no Russian, Ukrainian or Belarusian people, and everything will be melted down in a sort of civilizational cauldron" (Sviateishii Patriarkh Kirill 2014). ${ }^{42}$ Yet, although Kirill has stated that he does not "differentiate between Russians and Ukrainians" and advocates for their "spiritual unity," he concurrently claimed that the sovereignty of Ukraine must be accorded "full respect" (Interv'iu Sviatieshego Patriarkha Moskovskogo 2010). Nonetheless, while this civilizational vision encompasses far more than the Russian Federation and its titular 
nationality, Russia is almost always accorded primacy in such formulations. The remarks of Hegumen Filip (Riabych), made while he was Deputy Chairman of the Department of External Church Relations, reflect this: “Obviously, due to its rich spiritual and cultural heritage, natural resources, political gravitas and military potential, Russia cannot be part of a civilizational community in which it is not a recognized center, or at least one of the most important centers" (Zamestitel' predsedatelia OVTsS 2010). ${ }^{43}$

One manifestation of efforts to reinforce civilizational unity has been quite pragmatic: The Church has repeatedly sought to curry favor with foreign leaders seen as pro-Russian in their orientation and desirous of promoting Slavic unity. For example, Belarusian dictator Aliaksandr Lukashenka, despite being a self-professed "Orthodox atheist," has received no fewer than four prestigious awards from the ROC (this does not take into account additional awards presented to him by the autonomous Belarusian Church and other autocephalous ["self-governing"] Orthodox churches). ${ }^{44}$ Meanwhile, Viktor Yanukovych, one of the chief antagonists in the 2004-2005 Orange Revolution and Ukraine's head-of-state from 2010 until his ouster in February 2014, received the ROC's Order of Saint Equal-to-the-Apostles Prince Vladimir (first class) in July 2010 (Wołowski 2010). ${ }^{45}$

Regarding the second arena, the ROC's relations with other Eastern Orthodox Churches, especially the majority Slavic ones, are generally cordial. Here, the most significant contemporary rift is between the MP and the Patriarchate of Constantinople, colloquially referred to as the Phanar after the neighborhood in Istanbul where its administrative center is located. The ROC broke communion with Constantinople in October 2018 over Patriarch Bartholomew's decision to grant a tomos (i.e., an official proclamation) of autocephaly to Ukraine, leading to the creation of the Orthodox Church of Ukraine (OCU) (it has also subsequently cut ties with the Patriarch of Alexandria, Theodore II, as well as the Greek and Cypriot Churches over their recognition of the OCU, which it regards as a schismatic entity intent on expropriating the property and faithful of the UOC-MP). ${ }^{46}$ Despite the seriousness of the breach in relations between what is the most historically significant eastern Church and the ROC, numerically the largest Orthodox communion, ${ }^{47}$ there have been far more instances of cooperation and mutual support evinced among the autocephalous Orthodox Churches in recent decades than strife. Indeed, what is frequently overlooked by scholars is just how profoundly the bombing of Serbia by NATO in 1999 influenced the anti-Western stance of the ROC (and Kremlin). ${ }^{48}$ Patriarch Aleksii, who co-officiated a memorial service on 20 April 1999 in Belgrade with his Serbian counterpart Patriarch Pavel, had this to say about the intervention of Western states in the former Yugoslavia (Borisov 2019):

We are witnessing blatant lawlessness: Several strong and rich countries, insolently considering themselves the worldwide arbiters of good and evil, trample the will of people who want to live differently. Bombs and missiles are raining down on this land not because they are protecting someone. NATO's military actions have a different goal - to destroy the post-war world order paid for with great bloodshed, to impose an order alien to them, based on the dictatorship of brute force.

Demonstrating the enduring significance of the West's actions, on the twentieth anniversary of NATO's bombing campaign, Patriarch Kirill opined that the NATO states had "illegally attacked" Serbia, against which "double standards" had been applied. He added that "similar interventions" have subsequently occurred in the Middle East (Borisov 2019). ${ }^{49}$

As regards the third arena, soon after becoming patriarch Kirill, addressing the "many sicknesses with which contemporary civilization must contend," averred that the "common task before our peoples is not only to preserve our identity, but also to stimulate the healing process of the whole European continent, to help decide those economic, moral, and spiritual problems that Europe is today experiencing." Expressing the messianism inherent in his conceptualization of "the Russian way of life," he went on to assert that 
disseminating it beyond the Russian world could attenuate the "spiritual and moral crisis of contemporary human civilization" (Vystuplenie Sviateishego Patriarkha 2009).

However, the most substantial of the post-Soviet ROC's foreign policy successes in the far abroad occurred in 2007, while the Church was still under the leadership of Patriarch Aleksii. In May of that year, full ties were restored between the MP and the New York City-based Russian Orthodox Church Outside of Russia (ROCOR), a dissident religious body established by White Russian (i.e., pro-monarchist) émigrés in the wake of the 1917 Bolshevik seizure of power that did not recognize the legitimacy of the Soviet-era ROC. Although the reunification of ROCOR, which was once the MP's fiercest critic, with the ROC resulted in a series of schisms within the former body, it also transferred to the ROC's control a significant number of ecclesial properties around the world (including many in Europe, the MENA region, and both North and South America) that until then had been overseen by ROCOR. ${ }^{50}$

\subsection{Institutions Representing the ROC Abroad}

Especially as this concerns its more normative objectives, the Church has found likeminded allies not only in the Kremlin but also throughout Russian society (and even further afield). Although a systematic consideration of the role that influential laypeople and para-Church groups play in the ROC's ties abroad is beyond the scope of this article, their impact is substantial. With respect to the laity and its involvement in the institutional life of the Church, arguably the most prominent individual in this regard is billionaire businessman Konstantin Malofeev, dubbed the "Orthodox oligarch." A controversial figure with close ties to the Kremlin as well as the separatist movement in Ukraine, Malofeev is a member of the Patriarchal Commission on Family Matters and the founder of the St. Basil the Great Foundation, a prominent charitable organization. ${ }^{51} \mathrm{He}$ is also deputy head of the All-World Russian People's Council, an outgrowth of the ROC created in 1993 and currently presided over by Kirill that brings together leading governmental, religious, cultural, and other figures from across the Russian-speaking world, ${ }^{52}$ and-together with Vladimir Yakunin, another wealthy and well-connected Russian businessman-is involved in the World Congress of Families, a conservative transnational NGO co-founded by American and Russian academics (Stoeckl 2020a, p. 229). In Malofeev's assessment, Russia "is the only great power, the president of which is not ashamed to speak of his Orthodox Christian convictions. Russia in this sense represents hope for the world's two billion Christians" (V Rossii vozmozhno vse 2015).

As for the ROC's official cross-border contacts, these may be grouped into three main categories: one-on-one church-state interactions, interactions with international and supranational bodies (e.g., the United Nations [UN] and EU), and interactions with non-state actors, such as other religious bodies and civil society groups, either bilaterally or via organizations such as the WCC. ${ }^{53}$ (These can further be sub-divided by whether they constitute routinized channels of interaction or ad hoc contacts.) The Department of External Church Relations (DECR) serves, in effect, as the ROC's foreign ministry (it also represents the interests of autonomous ecclesial bodies that are affiliated with the ROC, including the Belarusian Orthodox Church and the UOC-MP). Founded in 1946, the DECR-which Kirill headed from 1989 to 2009-is responsible for maintaining ties to Orthodox Churches outside of Russia, along with other Christian and non-Christian religious communities. It likewise oversees relations with various international and transnational bodies, including governments, legislatures, and civic organizations. ${ }^{54}$ In light of this, Metropolitan Ilarion (Alfeev) of Volokolamsk, the current head of the DECR, characterizes its fundamental mission as being to "safeguard the external boundaries of our Church." Specifically, Ilarion identifies three areas of particular concern for the contemporary ROC: countering the ecclesial prerogatives claimed by the Phanar, expanding relations with other national Orthodox Churches, and addressing the on-going persecution of Christians "in the Middle East, North Africa, and a number of other regions of the world." Additionally, he also cites 
the challenges of secularism and aiding Syrians affected by the conflict in their homeland (Mitropolit Volokolamskii Ilarion 2021).

More recently, the ROC established a Permanent Representation of the Russian Orthodox Church to the European Institutions in Brussels, ${ }^{55}$ as well as a Representation of the Russian Orthodox Church to the Council of Europe, headquartered in Strasbourg. ${ }^{56}$ It likewise participates in the Committee of Representatives of the Orthodox Churches to the EU (CROCEU), founded in March 2010. ${ }^{57}$

During Kirill's tenure as patriarch, the institutions of the Church have become more bureaucratized but also simultaneously more decentralized (Solodovnik 2014, pp. 49-54). This latter trend has affected activities previously under the aegis of the DECR. ${ }^{58}$ For example, on 31 March 2009 the Holy Synod (the ROC's governing body) created a Department for Church-State Relations to facilitate "the implementation of relations with legislative bodies, political parties, professional and creative unions, and other civil society institutions in the canonical territory of the Moscow Patriarchate" (Zhurnaly zasedaniia Sviashchennogo Sinoda 2009). It likewise formed a Secretariat for Institutions Abroad (renamed the Administration for Institutions Abroad in 2010) in order to oversee the dioceses, monasteries, and other institutions that had previously been administered by ROCOR (V Russkoi Pravoslavnoi Tserkvi 2009).

In terms of the ROC's dealings with exogenous state actors, the most fraught relationship remains that between the Russian Church and Ukraine, with the former accusing Kyiv, along with regional/local authorities and various nationalist groupings, of discriminating against the UOC-MP and permitting the confiscation of its ecclesial properties by rival bodies in the wake of the 2013-2014 Maidan protests and subsequent formation of the OCU. ${ }^{59}$ This is not the only front of contention, however. More recently, the ROC inserted itself into the controversy over Montenegro's 2019 Law on Freedom of Religion or Beliefs and the Legal Status of Religious Communities, which threatened the Serbian Orthodox Church (SOC) with the loss of ecclesial properties. ${ }^{60}$ As initially ratified, this legislation would have nationalized these holdings if the SOC could not document ownership prior to 1918, when Montenegro was absorbed into the Kingdom of Serbs, Croats, and Slovenes. The law, modified to remove this requirement after the December 2020 parliamentary election in Montenegro installed a pro-Serbian government (Montenegro Lawmakers Change Religious Law 2020), was regarded as an effort by the Europhilic Montenegrin President Milo Đukanović and his supporters to promote the formation of a recognized, independent Montenegrin Orthodox Church (an uncanonical such body already exists), with the ROC likening Đukanović's actions to those of former president Petro Poroshenko in Ukraine (Mitropolit Ilarion: prevrashchenie Sviatoi Sofii 2020; Vlasti Chernogorii presleduiut 2020; Patriarshee i Sinodal'noe poslanie 2019). ${ }^{61}$

Concerning international and supranational entities, apart from the ROC's contacts with the EU and Council of Europe, the Church has also repeatedly engaged with the European Court of Human Rights (ECtHR). In the context of issues external to the Russian Federation, these interactions have focused on intra-Orthodox disputes (Rimestad 2015, pp. 40-42). ${ }^{62}$ It has likewise sought to influence the UN and engage with its constituents. For example, the ROC appealed to the UN for assistance in protecting members of the UOC-MP in Ukraine (Karmanau 2018), and has condemned the UN Children's Fund (UNICEF) for promoting LGBT rights (Statement by the Patriarch's Commission on the Family 2014). Moreover, it is an active member of the UN's Alliance of Civilizations and the World Conference on Interreligious and International Dialogue, the latter co-sponsored by the Inter-Parliamentary Union and UN. ${ }^{63}$

Meanwhile, with regard to the ROC's linkages to non-state actors, the most problematic relationship is between the MP and Phanar. As previously noted, the two sides have been embroiled in a long-standing dispute over the extent of the See of Constantinople's authority in the Orthodox world. Consequently, these disagreements are mainly jurisdictional in character, though doctrinal and theological issues are present as well (Bartholomew is 
regarded as a progressive figure, and is frequently referred to as the "Green Patriarch" for his commitment to environmentalism). However, although tensions have existed for centuries, matters escalated markedly after Constantinople made clear that it would support the creation of the OCU, thus breaking the canonical dependence of the Ukrainian Church on Moscow. ${ }^{64}$ The document authorizing this was formally signed by Bartholomew on 5 January 2019 against the strenuous objections of the ROC, which claimed that the Phanar did not have standing to grant autocephaly. ${ }^{65}$

\section{The Russian State's Priorities Abroad}

The exogenous objectives of the Russian state include protecting what it terms its "compatriots" (defined loosely as ethnic Russians, Russian-language speakers, and former Soviet citizens living beyond the borders of the Russian Federation) ${ }^{66}$ promoting the "Russian world" concept and its associated cultural, historical, and religious affinities; bolstering Russia's status as a regional center of power in an increasingly multipolar world composed of discrete civilizational blocs; and maintaining/increasing Moscow's influence in its so-called "near abroad," which replicates the geographic footprint of the USSR (while also encompassing much of the ROC's claimed canonical territory). Ideationally, meanwhile, Moscow harbors significant grievances against the West. This has led the Kremlin to emphasize "spiritual-moral values" in an effort to distinguish Russia from a Western world depicted as morally bankrupt and weakening in power but still capable of posing an existential threat to the Russian way of life. (As utilized by the state, this term has connotations that extend beyond the overtly religious, encompassing concepts related to patriotism and the cultural realm as well.) Moscow especially criticizes the consumerism, secularism, atomistic individualism, and homosexual rights "propaganda" emanating from the West and resents the insistence that these concepts be universally accepted. ${ }^{67}$ The ROC has proven a useful ally to the Kremlin across all of these foci.

Two critical documents for understanding the state's position are the 2021 National Security Strategy and the 2016 Foreign Policy Concept of the Russian Federation. In terms of the themes addressed therein, the former demonstrates particular concern over Russia's status and standing as a major power, the incitement of inter-ethnic and inter-confessional conflict, threats to Russia's "cultural sovereignty" arising from growing civilizational competition, instability in the global system, the distortion/ falsification of Russia's history (along with other expressions of Russophobia), and assuring the rights of compatriots residing abroad (as well as preserving/strengthening their identification with the Russian world, understood to encompass cultural as well as economic and political ties). ${ }^{68}$

Effectively, the text reads like a litany of grievances against the West buttressed by an alternate vision for the geopolitical future. Indicative of this, the term "spiritual-moral" appears 20 times in the current Security Strategy, while the stem for the word "spiritual" appears 4 times (Strategiia natsional'noi bezopasnosti 2021). (An entire sub-section of this document is titled "Protection of Traditional Russian Spiritual-Moral Values, Culture, and Historical Memory".) However, while this represents a sharp increase from previous usage, the deployment of such terminology is backed by long-standing precedent. ${ }^{69}$ For example, the 2000 National Security Concept discusses protecting the country's "cultural and spiritual-moral legacy, historical traditions and norms of social life," as well as preserving "the cultural heritage of all Russia's peoples" (Kontseptsiia national'noi bezopasnosti 2000). ${ }^{70}$ Meanwhile, the preceding text lauds the "critical role in the preservation of traditional spiritual values" played by the ROC "and churches of other denominations" (Kontseptsiia national'noi bezopasnosti 1997).

Citing a "problem of moral leadership" in the international system and the ensuing need to create "an attractive ideational basis for the future world order," the 2021 document argues that because of the crises the Western "liberal model" is experiencing, "a number of states are purposely attempting to erode traditional values, distort world history, revise views on the role and place of Russia within it, rehabilitate fascism, and kindle inter-ethnic and inter-confessional conflicts" (II.9). It also claims the West engages in "informational- 
psychological sabotage" and that its influence threatens Russia's cultural sovereignty (IV.88), with "foreign ideals and values" being "implemented without regard to historical traditions and the experiences of past generations" (IV.86). Specifically, Russia's traditional "spiritual-moral and cultural-historical values" are said to be "subjected to active attack from the side of the USA and its allies," as well as "transnational corporations, foreign non-commercial, non-governmental, religious, extremist, and terrorist groups" (IV.47.87). More generalized resentment is likewise directed towards states Moscow depicts as waning powers that presume to dictate to others how they should live (IV.95).

Consequently, the Security Strategy focuses on strengthening Russia's role "as one of the centers of influence in the contemporary world" (II.10). This is regarded as being hugely important given an international context "characterized by the formation of new global and regional centers of power," which results in "the sharpening of the conflict between these spheres of influence" (IV.34). The text also emphasizes the need to protect the rights and interests of the Russian Federation and Russian firms abroad (IV.101.14), including by ensuring compatriots retain their cultural identity (IV101.19), and strengthening "brotherly ties between the Russian, Belarusian, and Ukrainian peoples" (IV101.20).

The current Foreign Policy Concept focuses on a number of similar issues, among them increasing Russia's standing on the world stage, protecting the interests of compatriots around the globe, preserving traditional Russian values, and promoting perspectives favorable to Moscow in various international fora. It also stresses that civil society can play an important role in the realization of these aims (Kontseptsiia vneshnei politiki 2016). ${ }^{71}$

Article I.3.c specifically discusses the need to consolidate the Russian Federation's position as a major global power. The comprehensive protection of "the rights and legitimate interests" of Russian citizens and compatriots residing abroad (I.3.h) is also addressed, as is the need to raise awareness of the Russian language (along with Russia's culture and history) and unite the diaspora (I.3.i). The latter is understood to be particularly critical, as global competition "has increasingly been gaining a civilizational character, expressed in terms of competing values" (II.5). Of note, the Foreign Policy Concept explicitly mentions utilizing soft-power strategies along with traditional diplomatic approaches to achieve Russia's objectives beyond its borders (II.9).

Regarding compatriots, Moscow furthermore pledges to fortify "ties to the homeland," including supporting voluntary resettlement in the Russian Federation (III.45.f). It likewise commits to promoting Russian educational institutions abroad (III.45.g) and developing "cultural and humanitarian ties between Slavic peoples at the inter-state level" (III.45.h). This includes bolstering its partnership with Belarus (IV.50); fostering "a diverse array of political, economic, cultural and spiritual ties with Ukraine" (IV.56); and promoting cooperation within the Commonwealth of Independent States (CIS) "on questions concerning the preservation of a common cultural-historical legacy" (IV.55.a). Article III.38 is worth quoting in full, as it not only grants the ROC a central role in achieving the state's objectives but also implies that Russia has lessons to teach the world: ${ }^{72}$

The Russian Federation, as a multi-ethnic and multi-confessional state, having centuries-long experience with harmonious coexistence among various peoples, ethnic groups and religions, promotes the development of dialogue and the formation of partnerships between cultures, religions and civilizations, including within the framework of the UN and other international and regional organizations; it supports civil society initiatives to correspond to these aims and actively cooperates with the Russian Orthodox Church and the country's other main religious bodies to counter extremism, the radicalization of society, intolerance, discrimination, and division based on racial, ethnic, confessional, linguistic, cultural, and other grounds.

The document continues on to reaffirm a commitment to inter-civilizational, and especially inter-religious, dialogue in article III.45.k. Similarly, it highlights the need "to attract the institutions of civil society to address international problems with the aim of increasing the effectiveness of Russia's foreign policy" (III.45.j). 


\subsection{Representing the Kremlin across the Russian World (and Beyond)}

Just as with the ROC, we may distinguish spatially between the Russian Federation's relations with the other former Soviet states, its broader arena of cultural and/or significant diasporic influence, and more physically and notionally distal parts of the globe.

Regarding the first of these spheres, faith and politics have long been intertwined in the Russian Empire, leading the institutions of church and state to develop in tandem. (Nonetheless, there exist differences when it comes to their respective geographic reach and influence; this is most apparent in Central Asia, a majority Muslim region where, with the exception of Kazakhstan, the ROC never made significant inroads.) Consequently, it is not surprising that contention in this arena would today be concentrated on post-Maidan Ukraine.

Putin's 18 March 2014 speech announcing Russia's annexation of Crimea stressed that "ancient Chersonesus" (located on the peninsula) was where "the holy prince Vladimir accepted baptism" into Orthodox Christianity, an act that gave rise to the common civilizational traits that unite Russians, Belarusians, and Ukrainians. ${ }^{73}$ He proceeded to emphasize that the graves of Russian soldiers are located there, demarcating sites of important battles waged throughout Crimea going back to Tsarist times. In doing so, Putin conflated religious and military motifs in reflecting on these places, which are "sacred for us," as they are "symbols of Russian military glory and unprecedented valor" (Putin 2014b). ${ }^{74}$ Later that same year, in his annual address to the Federal Assembly, the Russian president proclaimed that Christianity was a powerful unificatory force that made the emergence of the Russian nation possible and likened the meaning of Crimea for Russians to what the "Temple Mount in Jerusalem is for those who practice Islam or Judaism" (Putin 2014a).

For Moscow, Ukraine represents a space where particularistic grievances compete for attention with broader themes (e.g., the purportedly anti-religious and anti-family values of the liberal West) that have been overlaid onto this territory. A good illustration of the latter concerns how Russian officials tie post-Maidan Kyiv's westward shift to the promotion of the rights of sexual minorities, which Moscow condemns as threatening societal stability. For example, during the Maidan protests, then-head of the Duma's Foreign Affairs Committee, Aleksei Pushkov, tweeted that as a condition of getting Iulia Timoshenko released from confinement (the former Ukrainian Prime Minister-turned-opposition leader was jailed in 2011 after being convicted of abusing her position in brokering a 2009 gas deal with Russia, though the trial was widely regarded as politically motivated), the EU would demand Ukraine widen its "gay culture." Then, as he put it, "instead of Victory Day parades in Kiev there will be gay parades" (Pushkov: posle dogovora 2013). ${ }^{75}$

Another cross-over topic in spatial as well as religio-political terms concerns the establishment of the OCU and the role played in this by the Patriarchate of Constantinople, along with other external actors. ${ }^{76}$ Answering a question posed by a reporter about Orthodoxy in Ukraine during his annual end-of-the-year press conference in December 2018 (when it was already known that the Phanar would proclaim the creation of an autocephalous Ukrainian church), Putin did not mention the word "Constantinople," instead calling it Istanbul and speaking of the "Turkish patriarchate." Moreover, he opined that Bartholomew, whom he did not refer to as patriarch, took the actions that he did "to subjugate this territory, and then to profit from it," while terming the involvement of the U.S. State Department in the matter "absolutely unacceptable" (Bol'shaia press-konferentsiia 2018). ${ }^{77}$ Russia's Foreign Minister likewise waded into this ostensibly ecclesial spat on the side of the ROC, but he extended the significance of what happened in Ukraine further afield, stating that the United States was apparently going beyond supporting the formation of the OCU and "trying to promote a split in the Orthodox world as a whole" (Lavrov: priznaniem PTsU SShA 2019). Lavrov followed up by declaring that Patriarch Bartholomew is acting under pressure from the U.S. to "bury the influence of Orthodoxy in the modern world" (Lavrov: patriarkh Varfolomei 2021). ${ }^{78}$

Relatedly, the Russian state also became enmeshed in the acrimonious debate over Montenegro's polarizing 2019 religion law. (The SOC and Serbia have traditionally been 
close allies of the ROC and Russia, whereas Montenegro, which gained its independence from Serbia in 2006 and is currently a candidate for EU accession, joined NATO in 2017.) ${ }^{79}$ Although the level of interventionism has not come anywhere close to that displayed relative to Ukraine, Russia's Ministry of Foreign Affairs (MFA) has signaled in no uncertain terms that it backs the SOC in this dispute, which, while cast as a bid to preserve Orthodox unity, has obvious hard-power geopolitical resonances (pro-Western Montenegrin politicians are seeking to establish a legitimate national Church to break Serbian and, by extension, Russian control over their country, while Moscow is looking to preserve its influence in the Balkans). Indicative of this conflation of religion and politics, MFA spokesperson Maria Zakharova stated that while Moscow's policy was to not interfere in the internal affairs of other states, the religious situation in Montenegro "extends beyond national boundaries and touches on the unity and cohesion of the Orthodox world," which has been negatively affected by the meddling of Western powers (Brifing ofitsial'nogo predstavitelia 2019). ${ }^{80}$

It should be noted that among the states that comprise the Orthodox world, there is genuine support evinced for Russia's foreign policy positions, and this extends beyond just the post-Soviet polities. For example, while 72 percent of Russians believe that "Russia has an obligation to protect Orthodox Christians outside its borders," so too do majorities in most other Orthodox countries, with respective figures ranging from 79 percent in Armenia to 56 percent in Bulgaria. The sole exception is Ukraine, where the number stands at 38 percent (Religious Belief and National Belonging 2017, p. 31). ${ }^{81}$ Likewise, in the arena of international relations, majorities in these states-Ukraine is again the only outlier-agree that "a strong Russia is necessary to balance the influence of the West" (Religious Belief and National Belonging 2017, p. 15). ${ }^{82}$

As regards the second sphere, Putin, speaking in Budapest in late 2019, remarked on the "massive exodus" of Christians from the Middle East and announced that supporting Christians in conflict zones such as Syria had become "a top priority" for Russia (Bos 2019). Highlighting the religious overtones inherent in the Syrian conflict, he had previously declared that Moscow planned to help Syrian Christians, as well as Muslims and Jews, restore holy sites affected by the fighting, underscoring that it, along with the ROC and "other religious organizations," had already provided humanitarian aid to the war-torn country (Putin: Almost All Syrian Territory Freed 2017).

This topic, however, came to be connected to wider geopolitical concerns. Lavrov, who had earlier labelled what ISIS was doing to Christians "genocide" (Paraszczuk 2015a), ${ }^{83}$ subsequently stated that one of the key missions of the MFA was to protect persecuted believers in the MENA, whose troubles he blamed directly on "geopolitical engineering by the United States and their closest allies" (Russia to Continue Providing Assistance 2019). ${ }^{84}$ Assuming such a rhetorical position provided the MFA with a convenient vantage point from which to criticize U.S. foreign policy in this region and beyond. "Christians have suffered and continue to suffer from geopolitical experiments carried out by countries of the so-called historical West," according to the Russian Foreign Minister, who reminded his audience in 2019 that two decades prior, "the North Atlantic Alliance committed an act of aggression against Yugoslavia, which resulted not only in the death of civilians, but also in an exodus of Orthodox Christians from Kosovo, in the desecration and destruction of cathedrals and shrines in this Serbian land, including those under UNESCO's protection" (Russia to Continue Providing Assistance 2019). ${ }^{85}$

Finally, with respect to the third sphere of the "far abroad," Russian officials have openly vilified the West, especially the U.S. and EU. "In a Europe that shamefully renounces its Christian roots," Lavrov contends, "an aggressive minority is persistently imposing pseudo-liberal values which are sometimes taken to absurd levels." According to him, this not only exerts a deleterious effect "on the moral well-being of European communities" but also "leads to growing sectarian tensions" (Russia to Continue Providing Assistance 2019). Lavrov furthermore observes that the West "stands united as never before and will do what it believes to be right in international affairs, while forcing others, primarily Russia and 
China, to follow its lead." ${ }^{86}$ Consequently, he suggests an unevenness in the foreign policies of Western states, arguing that they accuse Russia "of adopting an 'aggressive posture' in a number of regions," despite Moscow's actions being "aimed at countering ultra-radical and neo-Nazi aspirations in its immediate neighborhood, where the rights of Russians, as well as other ethnic minorities, are being suppressed, and the Russian language, education and culture rooted out" (Lavrov 2021). ${ }^{87}$

It is the contention that the contemporary West violates its own historical legacy by rejecting the tenets of Christianity and infringing on the rights of believers that provides the Kremlin with the most frequently invoked ideological ammunition against Europe and the United States. ${ }^{88}$ Such an appeal also constitutes a useful tool to divide those residing in the West, a tactic that Russia has shown itself ready and willing to employ in recent years. ${ }^{89}$ (Acknowledging this, the European Parliament adopted an anti-propaganda resolution on 23 November 2016 that specifically mentions the role played by religious organizations in Moscow's efforts to subvert the EU. $)^{90}$ Infringement of the human rights of Christians is an especially convenient moral cudgel to wield against the U.S., a country Russia depicts as a declining power that is hypocritical in the application of its policies and selective in their enforcement.

Painting itself as a major power that stands up for traditional Christian values and defends the rights of believers the world over permits the Kremlin to promote a foreign policy that combines normative ideas with a neorealist reading of the world order, which it views in terms of polycentric blocks of like-minded states with Russia at the helm of its respective geographic region. It also allows the West to be critiqued through the very human rights language it champions, the argument being that the imposition of external values that run counter to wider societal preferences constitutes a violation of democratic principles and cultural autonomy.

"People in many European countries," Putin asserted during the 2013 meeting of the Valdai Discussion Club, "are ashamed and afraid to talk about their religious affiliation." At the same time, European elites "are trying to aggressively impose this model on everyone, on the entire world." (Zasedanie mezhdunarodnogo diskussionnogo kluba 2013). Addressing the Federal Assembly later that same year, the Russian president elaborated (Putin 2013):

Today in many countries norms of morality and ethics are being reassessed, national traditions and differences between nations and cultures are being erased. The demand now is for society to not only recognize the sensible right of everyone to their freedom of conscience, political views and private life, but also the obligatory recognition of the equivalence-no matter how strange this might seem-between good and evil, which are opposite in meaning. Such a destruction of traditional values "from above" not only brings in its wake negative consequences for societies, but is also fundamentally anti-democratic, since it is carried out on the basis of abstract, theoretical ideas, contrary to the will of the national majority, which does not accept the ongoing changes and proposed revisions. ${ }^{91}$

Lavrov echoes these views: "Pushing Christian traditions and symbols to the sidelines of the public space," he argues, "erodes European cultural and civilizational identity." Moreover, Russia's foreign minister complains that secularism in the West has morphed from promoting the separation of church and state into "a fight against religion verging on militant atheism" (Lavrov 2017). He likewise decries the imposition of the EU's supranational norms on other countries, citing its promulgation of values that are "often formed in contravention of the civilizational tradition of Europe, based on Christianity" (Lavrov 2019). In particular, Lavrov excoriates what he views as the West's unbridled promotion of the rights and visibility of sexual minorities. "In a number of Western countries," he claims, "students learn at school that Jesus Christ was bisexual." 92 At the same time, the efforts of "reasonable politicians to shield the younger generation from aggressive LGBT propaganda are met with bellicose protests from an 'enlightened Europe'." Given this, Lavrov argues 
that not only is religion under attack but so too is the "genetic code of the planet's key civilizations" (Lavrov 2021).

Apart from adopting the ROC's positions on social issues, Putin's government has also involved itself directly in Church affairs on numerous occasions. The most notable of these occurred early on in his presidency, when in September 2003 the Russian leader met personally with the then-head of ROCOR, Metropolitan Laurus, and members of its governing synod in New York City to discuss its potential reunification with the ROC. ${ }^{93}$ Ultimately this effort was successful, in no small part due to Putin's direct intervention. As a result, in 2007 the two bodies restored full communion, effectively merging ROCOR into the administrative structure of the ROC, an act Yuri Zarakhovich claims "sealed the four-year long effort by Putin... to have the Moscow Patriarchate take over its rival American-based cousin and launch a new globalized Church as his state's main ideological arm and a vital foreign policy instrument" (Zarakhovich 2007) ${ }^{94}$ While not everyone will agree with this characterization, Lavrov admitted that "[w]e see in the revival of church unity a critical factor for the consolidation of the entire 'Russian World'." (Vstupitel'noe slovo Ministra 2007) ${ }^{95}$ At the very least, reunification blunted one of the most vocal institutional critics of the MP (and previously the Soviet regime), allowing Russia to expand its international influence in the United States, Western Europe, Israel/Palestine, and South America, regions where ROCOR controlled a number of ecclesial properties and enjoyed a meaningful presence among the Russian diaspora and Orthodox converts.

The Russian state has also engaged in church-related activities in other parts of the far abroad, in some cases literally building worship spaces. Notable among these has been the construction of the Cathédrale de la Sainte-Trinité in Paris. Completed in 2016, this edifice is located along the banks of the Seine near the Eiffel Tower. The property, which also houses a "spiritual-cultural center," was bought by the Russian government for approximately 100 million dollars in 2010, French President Nikolas Sarkozy granting permission for its construction after "intensive lobbying by Russian officials," including then-president Dmitrii Medvedev and then-prime minister Vladimir Putin (Campbell 2010).

\subsection{Institutional Bases of Church-State Relations in the Foreign Policy Arena}

There are formal institutional mechanisms through which consultation takes place between the Russia government and the ROC, and there are also myriad informal avenues of contact between them, both direct and involving intermediaries that promote the shared goals of church and state throughout the world.

Falling into the first category, a joint working group between the ROC and the MFA was established in 2003. In the words of Robert Blitt, this body allows the Church's actions to be "coordinated (and possibly modified) based on implications for-and advantages to-Russia's 'secular' foreign policy" (2012, p. 108). The Russian World Foundation, a quasi-governmental entity (its board of trustees is composed entirely of high-ranking state officials) formed by presidential decree in 2007, also exhibits close ties to the ROC, which is unsurprising given that its mission is to "to promote understanding and peace in the world by supporting, enhancing and encouraging the appreciation of Russian language, heritage and culture. ${ }^{\prime \prime 6}$ This is similarly the case with Rossotrudnichestvo, a federal agency set up in 2008 to deal with compatriots beyond Russia's borders. ${ }^{97}$

However, much cooperation regarding international and transnational matters occurs on an on-demand or one-off basis, just as it does relative to domestic politics. With regard to this second category, the MFA has been quite active in supporting various projects and working with Church officials to validate Russia's foreign policy stances. This has included sponsoring an initiative known as "Days of Russian Spiritual Culture," which in 2019 hosted approximately 100 events across 7 countries. ${ }^{98}$ The MFA has also sought to carve out a meaningful role for the ROC within the UN (Blitt 2012, pp. 114-17). Lavrov justifies such actions by observing that the Church's activities abroad mesh organically with the Foreign Ministry's emphasis on compatriots, contributing "to the strengthening of spiritual and cultural ties of the Russian world with the Motherland." Moreover, he 
contends that the Foreign Ministry and ROC are united by their shared understanding of the importance of inter-confessional and inter-civilizational dialogue, adding that "we very much appreciate the efforts of the Church aimed at developing such a dialogue on international platforms, including the Council of Europe and UNESCO, and see our task as creating the most favorable political and diplomatic framework for this work" (S.V. Lavrov: MID i Tserkov 2011).

\section{Analysis: Areas of Cooperation (and Dissent)}

As Tsygankov and Tsygankov (2010) have pointed out, Russian international relations theory consists of three divergent paradigms: Westernism, statism, and civilizationalism. Presently, Russia embraces the last of these, with the Kremlin and ROC viewing themselves as jointly fighting the universalist pretensions of Western liberal political and socio-cultural thought, which depend on a substantively secular and pluralist (meaning religiously relativist) worldview for their existence. ${ }^{99}$ Such critiques of the West are far from original. Instead, they replicate older modes of civilizational contestation, ${ }^{100}$ but ones now infused with a healthy dose of post-communist nostalgia and imperial longing. They also reflect the fact that the ROC has traditionally tilted in an Occidentophobic direction for theological as well as historical reasons. ${ }^{101}$

However, while stressing civilizational differences may be politically useful for the Russian state, as this allows geopolitics to be framed as a zero-sum contest, it also highlights the vulnerability that the Kremlin feels on the world stage. Powerful polities do not, as a rule, engage in such rhetoric; states that perceive themselves to be besieged and threatened do. We should not forget the economic hardships that have been caused by falling oil and gas prices in recent years or the isolation and ostracism Russia has experienced as a consequence of the West's imposition of sanctions in 2014 to punish Moscow for its actions in Ukraine. The fiscal problems that resulted from all this highlighted the need to legitimate the government on the basis of something other than economic performance. Nor should we overlook that the dissolution of the USSR in 1991 left millions of ethnic Russians and Russian speakers involuntarily living outside the borders of the Russian Federation, a situation tailor-made for the cross-border projection of power. Concurrently, the Soviet Union's collapse also rendered the ROC a self-consciously transnational institution to an extent that it had never been before.

In this unsettled context, the idea of ensuring Russia's "spiritual security" resonated, the term, just like its "spiritual-moral values" counterpart, encompassing concepts beyond the purely religious (it is understood as being closely tied to the maintenance of cultural distinctiveness (Curanović 2012, p. 142)). ${ }^{102}$ Juxtaposing Russian spirituality to Western values may therefore be understood "as a securitization move" (Laine and Saarelainen 2017, p. 24), with the West's alleged debasement coming to be framed as an existential threat (Østbø 2017). ${ }^{103}$ However, the flipside to the state's securitization of Orthodoxy is the attendant process of Orthodoxy's sacralization of the state, particularly its military and security apparatus. ${ }^{104}$ With every missile its priests bless, with every chapel it opens in a place like Lubianka, with every military cathedral it builds comes the attendant sanctification of security. This has the effect of blurring the lines between patriotism and holiness, while placing state institutions (and, albeit to a lesser degree, the political leaders that represent them) increasingly above reproach.

However, although worsening relations with the West have "dealt a very hard blow to any pro-Western lines in Russia, in particular, at the official level" (Lipman 2018), Russia continues to define itself primarily in relation to Europe. "The new conservative doctrine," as Maria Engström observes, "is very anti-Western, but it is not a denial of Russia's European identity; rather it is an argument for Russia's true European Christian identity that got lost in the bureaucratic body of the European Union" (2014, p. 376). ${ }^{105}$ Underscoring this, Lavrov recently insisted that "[g]eographically, historically, economically, and culturally, Russia was, is, and will remain an integral part of Europe" (Lavrov 2019). 
When it comes to church-state interactions in the field of international relations, there are issues on which the ROC and Kremlin converge, issues where the Church affects the state's agenda, and issues where the state impacts ecclesial narratives (Curanović 2019, p. 260). ${ }^{106}$ Most relevantly, the ROC has been incorporated into the Kremlin's foreign policy calculus along three critical dimensions: justifying and implementing Russia's compatriots policy, which Moscow insists gives it the authority to intervene in the internal affairs of states that are seen as violating the rights of ethnic Russians and Russian-speakers residing therein; ${ }^{107}$ projecting soft power beyond Russia's borders, mainly through the statesponsored (but Church-instigated) "Russian world" project; 108 and legitimating Russia's actions in conflict zones such as Syria ("protecting Christians") ${ }^{109}$ and Ukraine ("maintaining Slavic unity" while "fighting the falsification of history"), ${ }^{110}$ as well as more broadly ("opposing the militantly secular West and promoting 'true' European values").

Although they are unequal partners, the relationship between the ROC and Kremlin is one of interdependence, with the foreign policy valence of religious factors "situated somewhere between 'reasons for action' and 'assets' which can be instrumentalized for specific purposes" (Curanović 2012, p. 141). However, what is crucial to understand about the Kremlin's embrace of social conservatism is that the ROC provided much of the impetus and attendant justification for it, even if political expediencies rather than Church edicts have subsequently proven vastly more influential in determining Russia's foreign policy. Consequently, the state has converged on the ROC's positions because the rhetoric surrounding them is useful to deploy in competing against Western liberalism. As for the Church, its status as a non-state actor means that it "is limited in its ability to promote any specific foreign policy agenda," and therefore reliant on state institutions to advance "moral and cultural values that both the ROC and Russian state share" (Petro 2019, p. 220).

In this respect, the church of an empire has not reconciled itself to being the church of a nation-state (just as Moscow has not relinquished its insistence on maintaining a privileged sphere of influence in the post-Soviet space), even though the post-Soviet ROC has progressively come to behave not as a transnational entity but rather an ethno-national body with transnational interests. ${ }^{111}$ Despite protestations of impartiality, the ROC, at least at the institutional level, today exhibits overwhelming support for Moscow's dealings abroad. This was evident, for example, in Russia's Syrian campaign, where the ROC imbued the state with a messianic narrative that focused on the plight of persecuted Christians, pursued its own diplomatic efforts to legitimate the Kremlin's policy (including among Muslim audiences), and, via such avenues as the military clergy (which was reestablished in 2009), provided a "sense of purpose and mission" to Russian soldiers (Adamsky 2020). ${ }^{112}$

This manner of cooperation is not surprising given the history of relations between cross and crown in Russia. ${ }^{113}$ "It is the close church-nation tie that has determined Orthodoxy's central tendency (though not its only tendency) on security matters-namely, Orthodoxy has tended to align with the power of the state and to sacralize its security interests," writes Christopher Marsh (2012, p. 22). Similarly, John Anderson observes that although "it is difficult to speak of the Russian Orthodox Church as a monolithic body with a single viewpoint, its ideological center of gravity is much more inclined to a nationalistic and anti-Western perspective that has been shaped by Soviet-era thinking, 19th century anti-Western thought, and the much older East-West split in Christianity" (Anderson 2007, p. 187). ${ }^{114}$

As has been suggested above, the ROC's enduring political relevance lies not in its capacity to exert direct bearing on foreign policy decisions-where its actual, as opposed to symbolic, influence remains dubious-but rather in its ability to affect how threats are perceived (Blitt 2012, p. 105). Even so, the ROC's power to frame security concerns in the language of spirituality and moral obligation is a second-order effect, stemming from the state's appropriation of religious tropes and the didactic discourses that surround them. Additionally, the Kremlin is strategic in how it deploys such appeals. As Nicolai Petro observes (2019, p. 223): 
In the case of Crimea, Russian culture and Orthodox religion were used to popularize a policy that that had already been deemed in the strategic interests of the nation, whereas in the case of the Donbass similar appeals were ignored (some observers even say suppressed) because they did not correspond to Russia's strategic interests. The ROC had no discernible impact on immediate policy choices in either instance.

Western scholars, however, have often underestimated the soft-power potential of an illiberal Russia, whose political as well as cultural values increasingly appeal to "the growing populist and conservative constituencies in liberal democracies and across the world" (Keating and Kaczmarska 2019, p. 3). In this context, the ROC represents a critical civil society actor, with its brand of traditionalism finding a ready market among certain demographics abroad. ${ }^{115}$ For example, despite the fact that Russia's amended anti-extremism statute-enacted in 2016 under the guise of ensuring national securityaffects foreign missionaries by essentially prohibiting proselytism (Clark 2016), U.S.-based Evangelicals and the ROC have made common cause for some time, brought together by shared stances on traditional morality and an anti-secularist agenda. None other than that stalwart of American paleoconservatism, Pat Buchanan, lauded both Putin and the ROC for standing up for Christian values and oppressed believers in the Middle East (Buchanan 2013). Likewise, Franklin Graham featured Putin on the cover of the March 2014 issue of his Decision magazine, asking rhetorically, "Isn't it sad, though, that America's own morality has fallen so far that on this issue-protecting children from any homosexual agenda or propaganda-Russia's standard is higher than our own?" (Graham 2014). ${ }^{116}$ Meanwhile, in 2017, a "World Summit in Defense of Persecuted Christians" took place in Washington, D.C., with the Billy Graham Evangelistic Association reportedly spending 4 million dollars to bring together some 600 participants from 136 countries, which included a high-ranking ROC delegation. During this event, Metropolitan Ilarion of the DECR not only met privately with U.S. Vice President Mike Pence but also delivered a keynote address in which he warned "that while Christians in the West may not yet suffer physical violence for their faith, they increasingly experience social opposition and even discrimination because of their positions on abortion, sexuality, and euthanasia" (Burgess 2018).

At the same time, cooperating too closely with the government or backing its foreign policy positions represents a fraught undertaking, as the ROC risks losing its moral authority if it comes to be seen as simply a tool of Moscow. Nor do the Church's goals always align with those of the Russian state; despite the symbiosis achieved between the ROC and Kremlin in recent years, it is important to realize that the ROC also operates apart from the state and is "a moral agent in the international sphere in its own right" (Stoeckl 2016, p. 132). Indicative of all this, the MP has made an effort-irrespective of the underlying motivation-to distance itself from the state when the latter has taken controversial action within the Church's canonical territory. This explains why Kirill was conspicuously absent from St. George's Hall in the Kremlin when Putin announced the annexation of Crimea, despite usually being a prominent presence during presidential addresses, and why the MP has not transferred parishes located in Crimea's three dioceses away from the UOC-MP after the peninsula's annexation. Likewise, the MP did not assume control over parishes in Abkhazia after the 2008 Russo-Georgian War, allowing them to remain under the aegis of the Georgian Orthodox Church. Neither has it done so in South Ossetia, which reportedly provoked tensions with the MFA (Payne 2010, p. 724, ftn. 64). ${ }^{117}$

The reverse is true as well. For all that they today identify closely with the ROC, Russian officials are wary of appearing to favor the Church too overtly. Instead, the Kremlin promotes what can be thought of as a "common denominator" civil religion that conflates patriotism and martial themes, on the one hand, and traditional conceptions of morality and societal life, on the other. ${ }^{118}$ This formulation privileges the ROC, but it also conspicuously stresses the multi-confessional (and multi-ethnic) composition of the Russian Federation, along with the idea that "traditional values" are held in common by all the world's major religions. In this manner, the link between the state and "spiritual- 
moral values" (as opposed to their specific Orthodox Christian manifestations) is kept purposely vague and inclusive of other faiths, the intent being to appeal to the widest possible audience.

\section{Conclusions}

There is no doubt that the ROC and Russian state have worked closely together in recent years when it comes to the pursuit of foreign policy objectives. This has occurred, however, not because the Church has been subjugated by the state, but because Moscow has increasingly adopted stances relative to personal and societal morality that reflect positions the ROC has long championed. Such a move has allowed the MP to resume its traditional role of cooperating closely - though not always uncritically-with the apparatus of government. Concurrently, the Kremlin has been able to leverage the authority of the ROC to assist in legitimating its geopolitical objectives, which, while they are increasingly couched in principled justifications and normative language, continue to be informed by an essentially neorealist worldview that seeks to establish Russia as a leading actor in a polycentric conception of global power distribution.

The idea that Russia has a special role to play in the world is not exclusively an outgrowth of cordial relations between the ROC and Kremlin, though the Church certainly serves as a convenient vehicle through which to propagate this message. ${ }^{119}$ Given that civilizational appeals transcend fixed borders, the ROC has proven itself particularly adept at bolstering the efforts of state officials to deepen connections with Russian-speaking diasporic communities and like-minded "fellow travelers" around the world. The Church's soft power, however, extends beyond that of the Russian state; as such, the ROC has also been partnering with other religious bodies, including conservative Roman Catholics in Europe and Evangelicals in the United States, to bolster its "traditional values" platform on the global stage.

Consequently, the repeated references Russia makes to defending its cultural and spiritual distinctiveness are impossible to comprehend absent reference to inter-civilizational competition. In this paradigm, the main antagonist of the contemporary Russian state is the Western world, which is seen as promoting excessive permissiveness and individualism to the detriment of humanity's collective good. Accordingly, Russia's increasingly vocal claim that it is a defender of religious liberty and the rights of believers around the world not only substantially synchronizes its priorities with those of the ROC, but also appeals to a variety of disaffected constituencies in the liberal West.

Clearly, the geopolitical situation involving Russia today is highly dynamic (as this article is being finalized, Russian troops are massing along Ukraine's borders, and there is talk that an invasion is imminent). Equally clear, however, is that the ROC has played a substantial role in formulating and promulgating a socially conservative ideological platform that Moscow has increasingly hewed to in recent years, as well as collaborating with the state to advance the resultant political agenda. Still, more work needs to be done to elucidate the nature of church-state relations. With regard to better understanding Russia's priorities in the sphere of international relations and the method of their realization, these include two main directions for future research. First, it is necessary to go beyond studying official documents and pronouncements to better capture not just the range of opinions that exist in the ROC relative to the state (and vice versa) but also to more fully comprehend the network effects between key political and clerical leaders. It is not, for example, entirely clear how much of the current relationship between church and state is attributable to agent-specific effects versus institutional mechanisms of interest formation and articulation. Second, there is a need to examine, in sufficiently granular fashion, the respective attitudes of Russian political elites and ROC hierarchs toward one another.

In the final analysis, it was the Russian state that converged on the normative societal view of the Church after Putin was elected for third presidential term in 2012, rather than the other way around. This is not to imply that the ROC has the ability to meaningfully impact Russia's foreign policy agenda, but rather to indicate that the Kremlin found stressing 
civilizational competition a useful tactic to employ in pursuing its goals abroad. Since that time, the ties between them have been marked by mutual pragmatism. Moscow has taken a stance against what it depicts as rampant Western hedonism (without, however, renouncing claims to being a fundamentally European polity) in order to carve out a distinctive geopolitical identity for itself, while the ROC has utilized its improved access to the halls of power to pursue projects that are of interest to it. Chief among these is consolidating "Holy Rus'," which holds great meaning for the Church given that its canonical jurisdiction extends well beyond the present-day borders of the Russian Federation.

Funding: This research received no external funding.

Institutional Review Board Statement: Not applicable.

Informed Consent Statement: Not applicable.

Conflicts of Interest: The author declares no conflict of interest.

\section{Notes}

1 These words were written by Aleksandr Pushkin (1799-1837) regarding the Mongol invasion (widely considered Russia's greatest poet, as a young man Pushkin briefly served in the Tsarist Foreign Ministry). The epigraph points to a well-attested theme in Russia's foreign affairs that is repeated down to the present day, namely, the idea that Russia has more than once saved Europe from oblivion.

2 In 1914, the ROC had over 55.5 thousand parishes; in 1940, fewer than 500 were left. Moreover, between just 1937 and 1938 some 168 thousand clerics were arrested, the majority of whom perished (Sherr and Kullamaa 2019, p. 4).

3 Sergii had been acting patriarchal locum tenens since December 1925, when Metropolitan Peter (Polianskii) of Krutitsii was imprisoned just eight months after assuming the role of locum tenens in April 1925 following the death of Patriarch Tikhon (Bellavin). (Rumors that Tikhon had been poisoned by the Bolsheviks circulated widely at the time.) He became locum tenens after Peter was executed by the NKVD in 1937. Although he died in 1944, Sergii continues to the be a very polarizing figure in the ROC due to his 1927 declaration pledging the Church's loyalty to the new Soviet regime, an action that indelibly compromised him as a religious leader in the minds of many.

4 The available evidence suggests that many if not most of the ROC's hierarchs during the post-World War II period cooperated in some capacity with the NKVD and its successor organization, the KGB. This was personally confirmed to me in a 2007 telephone conversation with Fr. Gleb Yakunin, who, as a deputy of the Supreme Soviet of the Russian Federation and a member of the committee tasked with investigating the 1991 coup attempt, had direct access to the KGB archives in the early 1990s.

5 For a broader historical analysis of religion's use in the foreign policy of Russia/the USSR, see Curanović (2012).

6 While there is no research known to me that systematically examines the relationship between the Russian elite and the ROC, a comprehensive survey of societal attitudes toward religion carried out by the Pew Research Center demonstrates (its findings are in-line with other such surveys) that claiming to be Orthodox in post-communist Russia is mainly about asserting cultural and national identity, with far more people responding that they belong to the ROC than exhibiting belief in the core tenets of Orthodox Christianity (Religious Belief and National Belonging 2017).

7 The incongruity of its reputed birthplace not coinciding territorially with the Russian Federation's present-day borders is assuredly not lost on Moscow.

8 For his efforts, Vladimir was canonized with the exalted title of ravno-apostalnii ("Equal-to-the-Apostles").

9 The last royal family of Russia was canonized by the ROC as "passion-bearers," or those who faced death in a Christ-like manner. In contrast, the exile-led and fiercely anti-communist Russian Orthodox Church Outside of Russia had canonized them in 1981 as "new martyrs," or those who had been killed for their faith (after the fall of the Soviet Union the latter insisted on the canonization of the Romanovs as a preliminary step towards reunification with the ROC).

The original was destroyed by the Soviets in 1931; the current cathedral is a replica that was erected during the 1990s.

Victory Day, which marks the defeat of Nazi Germany in the Great Patriotic War (as World War II continues to be known in Russia), falls on this date, having become the preeminent Russian state holiday in recent decades. (However, in 2020 the COVID-19 pandemic forced its public commemoration to be postponed until June 24, when the initial Victory Day parade on Red Square took place in 1945.) The Cathedral itself was opened on 22 June 2020, the anniversary of Nazi Germany's attack on the USSR, which is now commemorated as the Day of Remembrance and Sorrow.

12 The structure is laden with symbolism; its metal floors, for example, were cast from melted-down Nazi tanks and other war trophies. Initially, there were also plans to adorn its interior with two controversial mosaics. One of these was to feature Stalin's image, while another would have depicted the annexation of Crimea, complete with the likenesses of Putin, Defense Minister Sergei Shoigu, and other government officials (Inside Moscow's New Military Megachurch 2020). However, both these projects were eventually scrapped. Putin reportedly objected to being depicted in this fashion (Russia Inaugurates Cathedral 2020; Russian 
Mosaic Featuring Putin 2020), while the potential display of Stalin's visage caused an understandable backlash within the ROC (Russian Orthodox Church Says 'No' 2020).

In the Orthodox world, neither the Patriarch of Moscow, nor the Ecumenical Patriarch of Constantinople (who has historically been recognized as primus inter pares, or "first-among-equals," within Orthodoxy), have the same hierarchical standing as the Roman Catholic Pope. While the Catholic model is centralized, the more conciliar Orthodox model has always been multivalent, with its five ancient patriarchates (the "pentarchy") comprising Rome, Constantinople, Alexandria, Antioch, and Jerusalem. However, the Moscow Patriarchate (established in 1589) has long claimed the greatest number of adherents, which has caused it to repeatedly challenge Constantinople (consult Keleher 1997).

Depicting Moscow as the inheritor of Constantinople's mantle after its fall in 1453 has a long precedent. The best-known example of this is the eschatological prophecy of the monk Filofei of Pskov, dating from the early 16th century, that "two Romes have fallen [the original and Constantinople, the new Rome], the third stands [Moscow], and there shall be no fourth." However, the idea of Moscow as the "third Rome" (i.e., the rightful successor to the Christian imperial project) was not embraced in governing circles until much later, only gaining traction in the latter half of the 19th century (Klimenko and Yurtaev 2018; Poe 1997).

During the post-communist period, the ROC has emerged as one of the most trusted Russian institutions, with a 2020 Levada survey finding 66 percent of respondents report they "completely trust" the military, 58 percent the president, 53 percent the FSB, and 42 percent the Church and religious organizations. In contrast, 36 only percent "completely trust" the police, 31 percent the courts, 29 percent the Duma, and 22 percent political parties (Doverie Institutam 2020).

It reads: "The Russian Federation is a secular state. No religion can be established as official or compulsory." Additionally, article 13.2 prohibits the imposition of any government-sponsored or otherwise mandatory ideology Available online: http: / / www.constitution.ru/10003000/10003000-3.htm (accessed on 2 January 2022). In reality, however, Russia is only secular insofar as it accords legal recognition to three other religions (Buddhism, Islam, and Judaism) deemed to be indigenous ("traditional") by the 1997 Law on Freedom of Conscience and Religious Associations. Even so, this legislation highlights the singular contribution that the ROC has made to the history of Russia and its spiritual-cultural development (see Daniel and Marsh 2007).

Although Yeltsin did claim that he was baptized. Putin is guarded when it comes to speaking about his own spirituality; however, while he has not unambiguously professed himself to be a believer, he has carefully cultivated such an impression.

It is worth noting that Putin referred to Russia as an "Orthodox power" as long ago as 2005, making the statement while visiting Mount Athos in Greece (Putin: Rossiia 2005).

By his third term, Putin was overtly blaming a perceived loss of morality (and what is for him the closely associated concept of patriotism) among Russians for creating, as he put it in his 2012 address to the Federal Assembly, "long-term threats for society, and the security and integrity of Russia." This caused him to argue that it is necessary to "fully support institutions that are the bearers of traditional values, which have historically proven themselves capable of passing them on from generation to generation" (Putin 2012). He was even more forceful in his 2013 speech to this same body, dismissing the West's "so-called tolerance" as "asexual and sterile," while emphasizing that Russia's historical responsibility in the world was growing and stressing the need to protect its values-driven approach, including in the sphere of international relations (Putin 2013).

As Maria Engström elaborates, this "new conservative narrative is characterized by strong messianism and anti-Western (antiAmerican) sentiment" (2014, p. 357). However, the beginnings of this trend considerably predate 2012, as witnessed by Putin's vituperative 2007 speech at the Munich Security Conference (Vystuplenie i diskussiia na Miunkhenskoi konferentsii 2007) and the Kremlin's party-of-power, United Russia, adopting conservatism as part of its political platform in 2009.

It also reflected longer-term legacies and more distal causes, including Western condemnation of Russia over the death of Sergei Magnitskii in 2009, international fallout from the 2008 Russo-Georgian War (and Georgia's associated departure from membership in the post-Soviet Commonwealth of Independent States), NATO's 2011 military intervention in Libya, and anxieties over the so-called "color revolutions" that roiled the post-Soviet space in the 2000s.

It is particularly well codified in the constitutional amendments that were adopted in 2020. Among other things, these recognize that Russians are "united by a thousand-year history, preserving the memory of ancestors who passed on to us our ideals and faith in God" (article 67; explicitly lobbied for by Kirill, this is the first mention of God in the Russian constitution since the 1906 Tsarist version was adopted (Patriarch Kirill Proposes 2020)) and pledge to protect the sovereignty of states (article 79). They also define marriage as being between a man and woman (article 72), commit to preserving "traditional family values" (article 114), and aver that the constitution supercedes the decisions of inter-governmental organizations relative to Russia's international treaty obligations (article 97) (Popravki v Konstitutsiiu RF 2020).

The ROC was not the only societal actor advocating for the adoption of socially conservative positions relative to Western progressivism, LGBT rights, and similar matters, but it was certainly the most vocal in this regard (and possessed the most coherent agenda).

Not all who identify as Russian Orthodox recognize the authority of the MP (or the legitimacy of its current leader) due to what they consider to be the insufficient contrition ROC leaders have exhibited for their past collaboration with the Soviet state. Adapted from the typology presented in Soroka and Rhodes (2020).

As Shekhovtsov argues, positioning Russia on the world stage as the leading proponent of "international conservatism" allowed Putin, who has a vested interest in dividing his domestic opposition (among whom social views run the gamut) and propping up 
not just the Russian state but his own rule, to seek legitimation "from a variety of Western political sources ranging from genuine conservatives to right-wing extremeists" $(2018$, p. 84).

In late 2017, Kirill stated that the ROC had 36,878 functioning parishes and 944 monasteries (Patriarkh Kirill nazval chislo 2017). In contrast, in 1988 the ROC only had around 7000 (Solodovnik 2014, p. 38). Although reliable figures are lacking, a great many of these continue to be located outside of Russia (in early 2017, over 12,000 parishes loyal to the MP were found in Ukraine alone (Soroka 2018b, Table 1), but this number has declined since the formation of the Orthodox Church of Ukraine in 2019).

Such stances, while quite prevalent in the ROC, are far from idiosyncratic; rather, for the most part they align with conservative Christian perspectives across denominations, as evinced in the joint statement that Patriarch Kirill and Pope Francis issued after their historic 2016 meeting in Cuba. Noting that the world has entered "a period of epochal changes," Francis and Kirill declared that "Christian conscience and pastoral responsibility do not allow us to remain indifferent" to societal challenges such as terrorism, same-sex marriage, abortion, euthanasia, and assisted reproduction. Moreover, the two church leaders emphasized the persecution of Christians throughout the MENA region and especially the dire refugee situation in Iraq and Syria. As for Europe, they declared that the continent needed "to be faithful to its Christian roots" so as to "preserve its soul, formed by a two-thousand-year Christian tradition" (Sovmestnoe zaiavlenie Papy Rimskogo 2016).

See, for instance, Kirill (2000). The current patriarch has been described as the "primary author" of the ROC's turn towards civilizationism (Lunkin 2018, p. 166).

One year prior, Kirill had given a speech in which he argued that if the Church continues to "repeat the phrase, which is loved by some, that politics is too dirty for us, that it is a non-Christian matter, then we will voluntarily surrender the life of the state into the hands of people who are at best indifferent to Christian moral values" ('Ob osnovakh sotsial'noi kontseptsii' 2008).

However, his statements on the matter have at times been contradictory. For example, Kirill declared soon after becoming patriarch that the ROC must remain autonomous from the state and "stay above the fray of politics." In this same interview, he noted that true symphonia has never been realized in practice, and that it is "more a dream than a real project of church-state relations" (Interv'iu Sviateishego Patriarkha Kirilla 2009). This is in contrast to earlier remarks wherein he had stressed the importance of this principle (see Solodovnik 2014, p. 55).

As article XVI.2 notes, "the danger of discrepancies between the will of the people and the decisions of international organizations should not be underestimated."

Apart from the spiritual damage materialism engenders, there is also a pragmatic reason for opposing it: According to Kirill, a non-believer living in a consumeristic world is not inclined to be patriotic or defend his homeland, whereas a believer-precisely because he thinks not just in terms of the material world-is disposed to do so (Otvety Sviateishego Patriarkha 2016).

In reality, the EU has historically been far from a secular project, though there is a tension between politics and religion inherent in its founding and continued functioning (Soroka 2017). Institutionally, meanwhile, Europe remains a continent "riddled with Christian privileges" (Klausen 2005, p. 555). As for religiosity in Russia, although surveys consistently show that somewhere in the neighborhood of 70 to 80 percent of Russians self-identify as Orthodox, a recent poll found that only 6 percent attend weekly services (Religious Belief and National Belonging 2017, p. 11), a rate that looks similar to that of Scandinavia, where church attendance is among the lowest in the world.

Relations between states, therefore, "should be based on the following foundational principles: love for one's neighbor, one's people and the Fatherland, an appreciation of the needs of other peoples, and a conviction that it is impossible for the good of your people to be served by immoral means" (VIII.3).

Article IV.9 explicitly notes that the exercise of an individual's rights "should not be destructive to the unique way of life and traditions of the family, as well as various religious, national, and social communities." This suggests that there is a practical point of compromise between the what the Church sees as universal moral criteria and the specific norms and mores of distinct peoples, though this is not elaborated on.

As Solik and Baar remind us, "the ROC became an important vehicle for the Russification policies of the Russian imperial regime in newly acquired territories" (Solik and Baar 2019, p. 21). As such, the goal of the Empire-era Church was not only to save souls but also to turn indigenous peoples into loyal subjects of the Tsar, a legacy that-along with Soviet-era policies that saw large numbers of ethnic Russians settle along the USSR's western periphery and in Central Asia—continues to be reflected throughout the post-Soviet states.

38 Kirill is widely recognized as a legitimate religious figure beyond Russia's borders, with the majority of Orthodox Christians in Estonia, Latvia, Belarus, and Moldova regarding him as the highest authority in Orthodoxy (Religious Belief and National Belonging 2017, p. 30).

The ROC has historically also enjoyed good relations with Armenia and Georgia (the former, however, is not in communion with the Eastern Orthodox Churches but rather part of the Oriental Orthodox world).

$40 \quad$ Kirill came to understand that his use of "Russian world" was being associated with Russian neo-imperialism in post-Maidan Ukraine (and elsewhere). Consequently, Lunkin reports that after expressing displeasure at the manner in which its meaning had been politicized (see Patriarkh prizval ne politizirovat' 2015), Kirill stopped utilizing the term because it required too much clarification to convey what he intended (2018, p. 171). Indeed, my keyword search of the MP's website (patriarchia.ru) for the period January 2016 to December 2021 revealed that although other Church officials continued to talk about the “Russian 
world," Kirill himself only referenced it in 1 speech out of the 101 documents the query returned (and here it was largely unavoidable, as he was addressing the 10th Assembly of the Russian World Foundation (Doklad Sviateishego Patriarkha Kirilla 2016)). Nonetheless, Kirill continues to employ it in his writing, as attested by the 2019 release of his book Dialog sistoriei, which features an entire chapter on the "Russian world" (V Moskve predstavili novuiu knigu 2019).

Regarding the eastern Slavic states of Belarus, Russia, and Ukraine, Kirill uses the analogy of three adult brothers to represent their relationship, noting that while each of them has "his own home, his own family, his own interests, [and] his own economy," what is apparent to all of them is "that only together will they be able to withstand adversity and move forward" (Slovo Sviateishego Patriarkha 2009).

Consequently, "civilizational diversity" must be protected; however, the reason for doing so is not to "recreate any political structures, build new empires, create military blocs, but to preserve the greatest heritage that we received from our ancestors" (Sviateishii Patriarkh Kirill 2014).

Elevated to the rank of archimandrite in 2019, he now serves as the ROC's representative to Europe in Strasbourg.

These include the Order of St. Seraphim of Sarov, 1st class (2015); the Order of the Holy Equal-to-the-Apostles Grand Prince Vladimir, 1st class (2007); the Order of the Holy Blessed Grand Prince Dmitrii Donskoi, 1st class (2005); and the Order of St. Sergius of Radonezh, 1st class (2002).

This is the highest award given out to laity by the ROC, in the highest of three ranked degrees. It was personally bestowed by Kirill, with whom Yanukovych reportedly enjoyed close ties.

Relations were similarly severed between the ROC and Phanar, albeit only for a few months, in 1996 over a dispute regarding Estonia (consult Sherr and Kullamaa 2019, pp. 22-28). However, one result of the current imbroglio is that on 29 December 2021 the MP established a Russia exarchate for Africa, infringing on territory traditionally controlled by the See of Alexandria. While this is widely understood as a response to Alexandria recognizing the OCU, Cyril Hovorun suggests that it may complement the Russian state's attempts to exert greater influence on the African continent, following in the footsteps of China (Hovorun 2022). While Bartholomew does not occupy a position equivalent to that of the Roman Catholic Pope, the Patriarch of Constantinople has traditionally exercised special prerogatives, among them the right to adjudicate disputes between fraternal Churches.

A particular point of contention concerns NATO's refusal to stop its bombardment on Orthodox Easter (which fell on April 11 in 1999), along with the fact that numerous churches and monasteries were damaged/destroyed by the aerial campaign. Moreover, in Russia photographs circulated of bombs with the message "Happy Easter" painted on them. This deeply offended the religious sensibilities of believers not just in Serbia, but throughout the Orthodox world.

The Social Concept (released in 2000) obliquely references the Serbian bombing campaign in article VIII.3: "In the current system of international relations, it is sometimes difficult to distinguish an aggressive war from a defensive one." However, despite the ROC's vociferous criticism of NATO's actions in Serbia (and later the West's involvement in the MENA region in the aftermath of the Arab Spring), Kirill defended Moscow's intervention in Syria, labelling it a "defensive war" intended to prevent terrorist groups from gaining power and possibly posing a threat to Russia (Russian Church Leader Defends 2016). As Robert Blitt writes, the "deafening silence" of the ROC in the face of credible allegations of war crimes committed by the Russian military in that country "betrays the full extent of the [Church's] unflinching support for the Kremlin's selective grasp of international norms" (Blitt 2021, p. 4).

Disputes over ownership had previously flared up in dramatic ways, as with ROC-instigated seizures of property in Jericho and Hebron by the Palestinian Authority (see Beshkin and Mank 2000; Schmemann 1997). The complexity of the matter was compounded by the fact that Tsarist-era ecclesial properties were frequently owned by the state and not the ROC.

Included in his holdings is Tsargrad TV, a conservative and pro-Orthodox broadcaster that Malofeev launched with the assistance of an American, former Fox News producer Jack Hanick, in 2015. A staunch monarchist, Malofeev criticizes Western powers for what he perceives to be their discrimination against believers and articulates a civilizational mission for Russia: "Just as Christians in the West in Ronald Reagan's time helped us against the evil of communism," Malofeev proclaims, "we now have to return our debt to Christians who are suffering under totalitarianism in the West" (Keating 2014). Available online: https:/ / vrns.ru/ (accessed on 2 January 2022). This body has been described as the "ideological center" of the ROC (Lunkin 2018, p. 166). Up until 2008, when it suspended its membership, the ROC also participated in the Conference of European Churches. Available online: https:/ / www.ceceurope.org/member-churches/ (accessed on 27 November 2021). Available online: https:/ / mospat.ru/ru/department/ (accessed on 27 November 2021).

Available online: https:/ / orthodoxru.eu/ (accessed on 27 November 2021).

Available online: http:/ / strasbourg-reor.org/ (accessed on 27 November 2021).

Available online: https://lobbyfacts.eu/representative/79b00aed228249288605d206a1b48817/ (accessed on 2 January 2022). Other members of this body include the Patriachates of Constantinople, Bulgaria, and Romania, along with the Churches of Cyprus and Greece.

The DECR is currently comprised of three divisions, respectively dealing with inter-Orthodox relations, inter-Christian relations, and foreign affairs with non-CIS states. 
In the immediate aftermath of the Maidan protests, the Moscow Patriarchate attempted to establish a very even-keeled approach to the unfolding conflict in Ukraine, with Kirill stating that the Church would not take sides in what amounted to a political struggle (Obrashchenie Sviateishego Patriarkha Moskovskogo 2014) and urging an immediate end what he characterized as "fratricide" and "internecine strife" (Obrashchenie Sviateishego Patriarkha Kirilla 2014). Since then, however, he and other highly placed figures in the ROC have been quite critical of the post-Maidan government in Kyiv and its supporters, whom they have-with some justification-repeatedly accused of targetting the UOC-MP (see, for example, Mitropolit Volokolamskii Ilarion 2019).

The Metropolitanate of Montenegro and the Littoral comprises a diocese within the SOC, which has historically enjoyed robust ties to Russia. For the text of the law, along with commentary from the Council of Europe's Venice Commission, see: https:/ / www.venice.coe.int/webforms/documents/?pdf=CDL-REF(2020)019-e (accessed on 15 January 2022).

The ROC clearly insinuated that the motivation for these actions originated with the Western powers (Patriarshee i Sinodal'noe poslanie 2019).

For example, in 2019 the UOC-MP sought legal relief for parishioners ejected from their church, allegedly with the connivance of government officials, in the Ukrainian village of Ptichya. Meanwhile, in 2020 there were two applications brought before the ECtHR by the Ukrainian Orthodox Church-Kyiv Patriarchate (UOC-KP) in Crimea requesting the Court prohibit Russian officials from expelling its members from the cathedral in Simferopol and demolishing a UOC-KP chapel in Yevpatoria, actions to which the ROC was an indirect but obviously interested party.

The next meeting of the latter body will take place in St. Ptersburg in May 2022, with Lavrov pledging to collaborate with the ROC in planning the event (Interv'iu Ministra inostrannykh del 2021).

Before the formation of the OCU, the three main Orthodox bodies in Ukraine were the UOC-MP, the UOC-KP, and the Ukrainian Autocephalous Orthodox Church (UAOC). However, the UOC-MP not only comprised the largest Church in Ukraine before the Maidan protests, but it was also the only one recognized as canonical by world Orthodoxy. (The UOC-KP and UAOC dissolved themselves in December 2018 in anticipation of the formation of the OCU, although internal squabbles lead to the re-establishment of the UOC-KP in 2019, albeit in a greatly diminished capacity).

Another proximate source of controversy between the two concerns the ROC (along with the Churches of Antioch, Bulgaria, and Georgia) pulling out of the Pan-Orthodox Council held in Crete in 2016 at the last minute, despite this event being over 50 years in the planning. Some believe that Bartholomew granted Ukraine's request for autocephaly, which was heavily pushed by the post-Maidan government, as a means of disciplining Moscow for attempting to scuttle the Council (at a meeting of Orthodox leaders in Switzerland in January 2016, Kirill had voiced concerns that representatives of Constantinople were supporting independence for the Ukrainian Church and complained about what he characterized as the illegal seizure of UOC-MP properties by schismatics and nationalists in the context of raising objections to how the planning for the Council was proceeding (Sviateishii Patriarkh Kirill vystupil so slovom 2016)). For his part, the DECR's Metropolitan Ilarion has stated that what Constantinople did was "revenge," though he denies that the MP intended to sabotage the Cretan meeting (Mitropolit Volokolamskii Ilarion 2019). Legally, compatriots are defined as Russian citizens permanently domiciled beyond the Russian Federation's present-day borders and individuals (along with their descendants) who are related to peoples that have historically resided on the territory of the Russian Federation, as well as persons who choose to maintain spiritual, cultural, and legal ties with the Russian Federation and whose direct ancestors lived in Russia or the Soviet Union (O gosudarstvennoi politike [1999] 2010).

As Maksim Shevchenko wrote in a widely noticed article critiquing the West, "[t]here is no more sin or holiness—there are desires, opportunities to achieve them and the permission of society." He continued: "Faith is antisocial, religion is radical and creates inequality. Here are the theses of neoliberalism, written over the entrance to the prison of the modern world" (Shevchenko 2013). The 2021 Security Strategy repeats many stresses already present in the prior 2015 text, which notably blames (article 17) the U.S. and EU for fomenting the 2013-2014 Maidan protests in Ukraine (Strategiia Natsional'noi Bezopasnosti 2015).

In the 2015 Security Strategy, the term "spiritual-moral" appears 12 times, 10 in relation to values and once each in reference to upbringing and education. More broadly, the term "spiritual" appears 4 times (Strategiia Natsional'noi Bezopasnosti 2015). In comparison, the 2009 Security Strategy uses the term "spiritual" or "spirituality" a total of 8 times, while the phrase "spiritualmoral" does not appear at all (Strategiia natsional'noi bezopasnosti 2009).

This text also mentions countering the "negative influence of foreign religious organizations and missionaries."

A clue as to how the Kremlin views the ROC and affiliated civil society organizations was revealed in Lavrov's comments about the Imperial Orthodox Palestine Society, a body formed in the 19th century to promote good relations in the Holy Land and to facilitate pilgrimage. The Foreign Minister noted that today, in addition to its spiritual dimensions, this organization is "a very important tool for the strengthening of Russia's positions" in the region (Lavrov: Imperial Orthodox Palestine Society 2016).

Such views are widely shared among Russian elites. For example, Irina Iarovaia, head of the Duma Security and Anti-Corruption Committee, observes that "the fundamental basis" of Russians' security resides in their "unique experience of multi-confessional and multi-ethnic unity and cooperation, which is based on respect." As such, she claims that "Russia provides an example for the whole world in its protection of spiritual-moral values, which have a common humane meaning, which protect against extremism and aggression" (Iarovaia: popytki sopriazheniia tekstov 2015). 
More recently, Putin (2021) referenced their shared Orthodox faith to justify why Russians and Ukrainians are part of the same ethno-cultural complex.

He also compared the annexation of Crimea to the West's support for carving out an independent Kosovo from Serbia, citing it as evidence of Western hypocrisy in international relations.

"Russian nationalist discourse presents European civilization as degenerate," Oleg Riabov and Tatiana Riabova write (Riabov and Riabova 2014), "and 'the perversion of the normal gender order' in the EU serves as clear evidence of this." As such, they note that Russia's anti-gay and anti-EU narrative (the two are in large measure connected) "offers a compensatory boost to Russian identity, not only in terms of helping to rehabilitate Russianness but by offering a new version of the messianic idea." To wit: "As a stronghold of Christianity and a bastion of traditional values, Russia will save Europe and the world."

Indicative of the relevance Constantinople's granting of autocephaly to the Ukrainian Church has for the Kremlin, it was discussed in Russia's Security Council on 12 October 2018 (Putin obsudil s Sovbezom 2018).

Washington's diplomatic efforts made clear its desire for an independent Ukrainian Church (Ponomariov 2019, p. 9). Moreover, in the fall of 2018 the U.S. State Department put out two statements supporting Ukrainian autocephaly. Then-Secretary of State Mike Pompeo subsequently tweeted on 3 January 2021 that he had "made sure the U.S. supported international recognition of the Orthodox Church of Ukraine" and "helped the Metropolitan [Epiphanius, head of the newly created OCU] escape Russian influence" (Pompeo Tells of U.S. Help 2021).

More specifically, he claimed that the United States is "openly seeking to drive a wedge into the Orthodox world, whose values are viewed as a powerful spiritual obstacle for the liberal concept of boundless permissiveness." (See also Lavrov: US backs Patriarch Bartholomew's Provocation 2018).

This occurred despite the Kremlin's concerted efforts to interfere with its accession to this organization (Milosevich 2020). Montenegro likewise recognized Kosovo's independence in 2008 (a particularly sore point for Serbia) and backed the imposition of Western sanctions on Russia in the wake of the 2014 Ukraine crisis.

She also drew an explicit analogy between the situation in Montenegro and Ukraine.

Additional countries surveyed included Belarus, Greece, Georgia, Moldova, Romania, and Serbia.

Aside from Russia, wherein 85 percent of respondents agreed with this statement, the respective figures ranged from 83 percent in Armenia to 52 percent in Georgia and Romania.

Lavrov made this comment at a meeting concerning the protection of Christians put together by Russia, Lebanon, and Armenia, which occurred in Geneva on the sidelines of the 2015 assembly of the UN Human Rights Council (UNHRC). In recent years the MFA and ROC have partnered with other each other and various religious and political leaders to address the issue of persecuted Christians in both the UNHRC and the Organization for Security and Co-operation in Europe (OSCE) (Interv'iu Ministra inostrannykh del 2021).

This has been a consistent theme in recent years. For example, Russian Deputy Foreign Minister Mikhail Bogdanov characterized the beheading by ISIS militants of 21 Coptic Christians in Libya as "a consequence of what has been done [in Libya] by Western partners" (Paraszczuk 2015b). Similarly, Lavrov excoriated "the irresponsible policy of several Western countries aimed at regime change in the region," as a result of which "vast territories in the Middle East have turned into a zone of chaos and instability and have become breeding grounds for terrorism and extremism, as well as a source of illegal migration." Further noting that followers of Jesus are being persecuted and their religious sites destroyed, he stated that the resultant "mass exodus of Christians upsets the established ethnic and religious balance in the region that has evolved over centuries" (Lavrov 2017).

Indicative of the enduring salience of this event for Russia's relations with the West, on the twentieth anniversary of the bombing Aleksandr Lukashevich, the permanent representative of the Russian Federation to the OSCE, produced a statement that criticized NATO (and particularly the U.S.) for attacking Serbia, calling it an act of aggression that violated Serbian sovereignty and underscoring that messages mocking Serbs were "scrawled by pilots from NATO countries on bombs and missiles" (Lukashevich 2019).

However, Lavrov sees matters already beginning to change, arguing that "clearheaded" Western politicians are coming to recognize "that the world has more than just one civilization, that Russia, China and other major powers have a history that dates back a thousand years, and have their own traditions, values, and way of life" (Lavrov 2021).

According to him, Western states "also dislike the fact than Moscow stands up for countries that have fallen victim to Western gambles, have been attacked by international terrorists and risked losing their statehood, as was the case with Syria".

As Putin explained not long after the start of his third presidential term, the "Euro-Atlantic countries" have renounced their roots and along with them Christian values, "which form the basis of Western civilization." As a result, they equate "a large family and same-sex partnership, faith in God or faith in Satan" (Zasedanie mezhdunarodnogo diskussionnogo kluba 2013).

Among other means of accomplishing this goal, the ROC now has a network of parishes in the EU that can be utilized to mobilize public opinion against liberal European values (Alekseev 2017, pp. 269-70).

Article 8 of this document notes that: "the Russian Government is employing a wide range of tools and instruments, such as think tanks and special foundations (e.g., Russkiy Mir), special authorities (Rossotrudnichestvo), multilingual TV stations (e.g., RT), pseudo news agencies and multimedia services (e.g., Sputnik), cross-border social and religious groups [sic], as the regime 
wants to present itself as the only defender of traditional Christian values." Available online: https://www.europarl.europa.eu/ doceo/document/TA-8-2016-0441_EN.html (accessed on 15 November 2021).

The idea that Western elites are imposing controversial political agendas that run contrary to the will of their own societies is also a theme that Kirill has emphasized (see Sostoialas' bratskaia beseda 2014).

For more about this bizarre (and untrue) claim, see Western Schools Teach (2021).

Mikhail Pozdnyayev explains Putin's intervention in these terms: “The ROC, the ROCA [Russian Orthodox Church Abroad, another name for ROCOR] and the Russian president are all pleased that the idea that a 'superpower' like our country should have a 'superchurch' is being advanced as the main argument in favor of reunification" (Pozdnyayev 2004).

During the reconciliatory service, which took place in Moscow's rebuilt Cathedral of Christ the Savior, Patriarch Aleksii was effusive in his praise of the role Putin played in reuniting the two bodies.

He went on to observe that the Foreign Ministry, along with Russia's embassies and general consulates, "always cooperate with parishes of the Russian Orthodox Church in different countries, with representatives of the Moscow Patriarchate," noting that they are "doing the same significant and much-needed work for the country".

Available online: http:/ / russkiymir.ru/en/fund/index.php (accessed on 15 November 2021). It is chaired by the deputy head of the Presidential Administration, Dmitrii Kozak, and, in addition to Lavrov, its members include Sergei Kratsov (Minister of Education), Olga Liubimova (Minister of Culture), and Valerii Falkov (Head of the Ministry of Education and Science).

Available online: https: / rwp.agency / (accessed on 12 January 2022). In 2015, when the 1000th anniversary of Grand Prince Vladimir's repose was commemorated, Rossotrudnichestvo and the ROC held approximately 150 events in 54 non-post-Soviet countries, along with 50 or so in the CIS and Baltic states (Mitropolit Volokolamskii Ilarion 2015).

Available online: https:/ / russkiymir.ru/en/news/280562/ (accessed on 27 November 2021).

While many would claim these are Enlightenment values, they only make sense in a post-Reformation world, the latter being a phenomenon that Russia, unlike the rest of northern Europe, never experienced directly (despite being indirectly affected by it in a myriad of ways, including some that were quite profound). Consequently, the ideological premises upon which liberalism was built are largely alien to its worldview. The ROC's stance therefore reflects not just a rejection of Western secular arguments concerning human rights but also a fundamental ontological and epistemological incompatibility with them.

Ninteenth-century Slavophiles would have immediately recognized arguments disparaging the Western world as decadent and envervated.

Theologically, this in significant measure results from its emphasis on apophatic as opposed to cataphatic understandings of the Divine. Historically, meanwhile, the relationship between Western and Eastern Christians has been colored by centuries of religious and political acrimony that neither side has forgotten. See, for example, the 2008 documentary Gibel' imperii. Vizantiinskii urok ("Death of an Empire: The Lesson of Byzantium"), which is narrrated by Metropolitan Tikhon (Shevkunov), a well-known religious figure in Russia who is reputedly Putin's father-confessor. In it, Tikhon casts the collapse of the Byzantine Empire as brought on by Western perfidy and makes a series of thinly veiled comparison between its demise and contemporary Russia's situation.

On the genesis and uses of this concept, see Marsh (2012); Payne (2010); and Bespal'ko (2006).

Already in 2007, Putin was comparing Russia's "traditional confessions" to its "nuclear shield," arguing that both "strengthen Russian statehood and create the necessary prerequisites for ensuring the country's internal and external security" (Stenograficheskii otchet o press-konferentsii 2007).

This is especially palpable when it comes to Russia's nuclear forces (Adamsky 2019). The Church, however, is not unwavering in its support; indicative of a more nuanced position, in 2020 the ROC considered instituting guidelines that would discourage priests from blessing nuclear arms and other weapons of mass destruction (Balmforth 2020).

Illustrative of this way of thinking, Igor Kholmogorov (2019) writes that "[i]t is Moscow, and not Paris that today defends the values of the European tradition, the high state of European culture".

Respective examples include outreach to the Russian diaspora, the ROC's push to regain ecclesial properties abroad that were lost as a result of the 1917 Revolution, and the manner in which the ROC has adopted the geopolitical language of multipolarity as a complement to its emphasis on preserving cultural distinctions.

The Church's understanding of what constitutes the "Russian world" expanded well past the borders of the former Soviet states in the 2010s (Lunkin 2018, pp. 166-68), paralleling Moscow's widening application of the concept. (This latter phenomenon can be traced back to the so-called Medvedev Doctrine, first articulated in the aftermath of the August 2008 Russo-Georgian war; among its other precepts, it averred that Russia would protect "the lives and dignity" of its citizens "wherever they might be" (Friedman 2008)). Reflective of this, Kirill stated during the 12th annual All-Wold Russian People's Council that "[i]t is our common duty to protect the rights of our compatriots abroad, their interests, in whatever part of the planet they live" (Sviateishii Patriarkh Kirill obratilsia 2021).

The idea of the "Russian world" was circulating long before the Kremlin claimed it for its own, having been initially promoted by the ROC and in various academic and political groupings (Pieper 2020, p. 771). However, there exist distinctions in how the Church and Kremlin understand this concept. For the ROC, it predominantly embodies a religious meaning, whereas it exhibits 
overwhelmingly geopolitical connotations for the Russian state (Petro 2015; Jarzyńska 2014, pp. 6-7). (Nonetheless, the term also displays "clear geopolitical and statist projections" for Kirill (Suslov 2015, p. 45)).

Historical ties and precedents are frequently invoked by politicians and Church leaders to justify Russian interest in the MENA region. For example, in speaking about the post-Arab Spring plight of Christians in this part of the world, Kirill reminded the then-head of the Assyrian Church of the East, Mar Dinkha IV, that Russia saved many Assyrians from genocide in the waning days of the Ottoman Empire (Patriarkh Kirill vstretilsia s Predstoiatelem Assiriiskoi Tserkvi 2014).

The ROC has become a key partner of the state in promoting a Russophilic version of history. This includes a pro-Soviet narrative of World War II, though the ROC is otherwise quite critical of the USSR (and particularly its Stalinist period). For his part, Lavrov has declared that the MFA is "open to close cooperation" with the ROC and "other traditional religions in our country" when it comes to providing historical education for Russian youth (Lavrov 2020). See the intriguing argument made by Kristina Stoeckl (2020b) about the post-Maidan nationalization of the ROC.

Archpriest Vsevolod Chaplin, the then-head of the ROC's Synodal Department for the Cooperation of Church and Society, encapsulated this logic when he noted that Russia's decision to intervene in the Syrian conflict reflected its long-standing role as a peacekeeper in the Middle East, where Christians were experiencing genocide. He went on to opine that the fight against terrorism was "a very moral fight; it is, if you will, a sacred fight" (Tserkov i voina 2015).

Russian diplomatic efforts have traditionally accorded a role to Church leaders, with the latter either acting as overt agents of the state or in a more informal capacity, and this has continued in the post-Soviet period (Curanović 2012, pp. 146-47).

Regarding the first of these influences, the idea of immorality in society stemming from the demise of the USSR is frequently encountered in contemporary Russia. Putin has himself drawn positive comparisons between communist and Christian values (Valaam: Vladimir Putin o pravoslavii 2018).

A 2019 survey found that 33 percent of U.S.-based respondents who identified as Republicans agreed with Putin on matters of international relations and 60 percent believed he was a good leader for Russia (Hale and Kamenchuk 2020). Similarly, 31 percent of Republicans or those who lean Republican reported that they "have confidence in Russian President Vladimir Putin to do the right thing concerning world affairs." The commensurate figure for Democrats or those who lean Democrat was 10 percent (About a Third 2020).

Putin embodies a form of unapologetic "muscular Christianity" that appeals to a certain segment of the political right. The Scottish journalist and conservative commentator Gerald Warner conveys this position when he writes: "The contrast between the West and Russia is one of infatuated liberalism, cultural masochism, indigenous depopulation, loathing of the family and hedonism substituted for personal responsibility in confrontation with a virile nation, firm political will and ruthless pursuit of national interest. The clever money is not on the Western wimps" (Warner 2013).

Though the Russo-Georgian War did cause tensions to flare between the two national Churches (Kishkovsky 2008). Moreover, we need to be careful in interpreting the MP's actions in Crimea and the two breakaway regions of Georgia as signifying substantive disagreement with the Kremlin's policies. Although it is understandable why the ROC would want to give the appearance of neutrality in these instances, its subsequent statements and activities have generally been supportive of the Russian state's position. On the topic of civil religion in Russia, consult Mitrofanova (2018).

\section{References}

About a Third of U.S. Republicans have Confidence in Putin, Up Significantly Since 2015. 2020. Pew Research Center, February 6. Available online: https://www.pewresearch.org/fact-tank/2020/02/07/russia-and-putin-receive-low-ratings-globally/ft_20 20-02-07_russia_07 / (accessed on 25 June 2021).

Adamsky, Dmitry. 2019. Russian Nuclear Orthodoxy: Religion, Politics, and Strategy. Stanford: Stanford University Press.

Adamsky, Dmitry. 2020. The Role of the Russian Orthodox Church in Moscow's Syrian Campaign. PONARS Eurasia Policy Memo No. 635, February 10. Available online: https:/ / www.ponarseurasia.org/the-role-of-the-russian-orthodox-church-in-moscow-ssyrian-campaign/ (accessed on 12 January 2022).

Alekseev, Nikolai V. 2017. Uchastie tserkovnykh organizatsii v mezhdunarodnykh otnosheniiakh. Problemy Postsovetskogo Prostranstva 4: 265-72. [CrossRef]

Anderson, John. 2007. Putin and the Russian Orthodox Church: Asymmetric Symphonia? Journal of International Affairs 61: 185-201.

Armes, Keith. 1992. Chekists in Cassocks: The Orthodox Church and the KGB. Demokratizatsiya 1: 72-84.

Balmforth, Tom. 2020. Russian Priests Should Stop Blessing Nukes: Church Proposal. Reuters, February 4. Available online: https:/ / www.reuters.com/article/us-russia-church/russian-priests-should-stop-blessing-nukes-church-proposal-idUSKBN1ZY2H6 (accessed on 25 November 2021).

Beshkin, Abigail, and Rob Mank. 2000. Hunger Strike in Jericho. Salon, March 24. Available online: https://web.archive.org/web/20 090218205540/http:/ / archive.salon.com/news/feature/2000/03/24/stephanopoulos/index.html (accessed on 25 November 2021). 
Bespal'ko, V. G. 2006. Dukhovnaia bezopasnost' kak ob"ekt ugolovno-pravovoi okhrany. Pravo i Bezopasnost', December, $3 / 4$. Available online: https://dpr.ru/pravo/pravo_19_33.htm (accessed on 14 August 2021).

Blitt, Robert C. 2012. Whither Secular Bear: The Russian Orthodox Church's Strengthening Influence on Russia's Domestic and Foreign Policy. The Journal of the International Religious Liberty Association 2011: 89. [CrossRef]

Blitt, Robert C. 2021. Religious Soft Power in Russian Foreign Policy: Constitutional Change and the Russian Orthodox Church. Berkley Center for Religion, Peace \& World Affairs. May. Available online: https:/ / berkleycenter.georgetown.edu/publications / religioussoft-power-in-russian-foreign-policy-constitutional-change-and-the-russian-orthodox-church (accessed on 27 November 2021).

Borisov, Aleksandr. 2019. Patriarkh Kirill: Serby stradali ot bomb NATO, tak kak borolis' za svobodu. Rossiiskaia Gazeta, April 30. Available online: https:/ /rg.ru/2019/04/30/patriarh-kirill-serby-stradali-ot-bomb-nato-tak-kak-borolis-za-svobodu.html (accessed on 27 November 2021).

Bos, Stephen J. 2019. Hungary \& Russia to Protect Persecuted Christians in Middle East. Vatican News, November 1. Available online: https: / / www.vaticannews.va/en/world/news/2019-11/russia-hungary-protect-persecuted-christians-middle-east. html (accessed on 12 October 2021).

Buchanan, Pat. 2013. Post v. Putin-Whose Side Are You On? Townhall, August 13. Available online: https://townhall.com/ columnists / patbuchanan/2013/08/13/post-v-putin--whose-side-are-you-on-n1662568 (accessed on 12 June 2021).

Burgess, John P. 2018. The Unexpected Relationship between U.S. Evangelicals and Russian Orthodox. The Christian Century, August 2. Available online: https://www.christiancentury.org/article/features/unexpected-relationship-between-us-evangelicals-andrussian-orthodox (accessed on 12 June 2021).

Campbell, Matthew. 2010. Onion Domes to Rise in Paris. The Times, June 6.

Clark, Elizabeth A. 2016. Russia's New Anti-Missionary Law in Context. Religious Freedom Institute. August 30. Available online: https:/ / www.religiousfreedominstitute.org/cornerstone/2016/8/30/russias-new-anti-missionary-law-in-context (accessed on 12 January 2022).

Curanović, Alicja. 2012. The Religious Factor in Russia's Foreign Policy. New York: Routledge.

Curanović, Alicja. 2019. Russia's Mission in the World: The Perspective of the Russian Orthodox Church. Problems of Post-Communism 66: 253-67. [CrossRef]

Curanović, Alicja. 2021. The Sense of Mission in Russian Foreign Policy: Destined for Greatness! New York: Routledge.

Daniel, Wallace L., and Christopher Marsh. 2007. Editorial: Russia's 1997 Law on Freedom of Conscience in Context and Retrospect. Journal of Church and State 49: 5-17. [CrossRef]

Engström, Maria. 2014. Contemporary Russian Messianism and New Russian Foreign Policy. Contemporary Security Policy 35: 356-79. [CrossRef]

Friedman, George. 2008. The Medvedev Doctrine and American Strategy. Geopolitical Intelligence Report, September 2. Available online: https:/ / worldview.stratfor.com/article/medvedev-doctrine-and-american-strategy (accessed on 12 January 2022).

Graham, Franklin. 2014. Putin's Olympic Controversy. Decision, February 28.

Hale, Henry E., and Olga Kamenchuk. 2020. Why are Republicans Using Putin's Talking Points? This Study Helps Explain. The Monkey Cage, February 4. Available online: https:/ / www.washingtonpost.com/politics/2020/02/04/why-are-republicans-using-putinstalking-points-this-study-helps-explain/ (accessed on 15 November 2021).

Hovorun, Cyril. 2022. Russia's 'Scramble for Africa' and Its Church. Public Orthodoxy, February 1. Available online: https:// publicorthodoxy.org/2022/02/01/russias-scramble-for-africa/ (accessed on 2 February 2022).

Huntington, Samuel P. 1996. The Clash of Civilizations and the Remaking of World Order. New York: Simon \& Schuster.

Jarzyńska, Katarzyna. 2014. Ukraińska gra patriarchy Cyryla. OSW Komentarze 144: 1-10.

Karmanau, Yuras. 2018. Russian Orthodox Church Calls on UN for Help in Ukraine. Associated Press. December 14. Available online: https:/ / apnews.com/article/moscow-belarus-germany-petro-poroshenko-france-b29240505c6745309f40bd9751444749 (accessed on 12 October 2021).

Keating, Joshua. 2014. God's Oligarch. Slate, October 20. Available online: https://slate.com/news-and-politics/2014/10/konstantinmalofeev-one-of-vladimir-putins-favorite-businessmen-wants-to-start-an-orthodox-christian-fox-news-and-return-russia-toits-glorious-czarist-past.html (accessed on 27 November 2021).

Keating, Vincent Charles, and Katarzyna Kaczmarska. 2019. Conservative Soft Power: Liberal Soft Power Bias and the 'Hidden' Attraction of Russia. Journal of International Relations and Development 22: 1-17. [CrossRef]

Keleher, Serge. 1997. Orthodox Rivalry in the Twentieth Century: Moscow Versus Constantinople. Religion, State, and Society 25: 125-37. [CrossRef]

Kholmogorov, Egor. 2019. Pochemu Rossiia-Evropa, a Evrosoiuz ... ne ochen'. Tsargrad.tv, August 21. Available online: https: // chita.tsargrad.tv/articles/pochemu-rossija-evropa-a-evrosojuz-ne-ochen_213564 (accessed on 29 October 2021).

Kishkovsky, Sophia. 2008. Conflict Tests Ties Between the Georgian and Russian Orthodox Churches. New York Times, September 5.

Klausen, Jytte. 2005. The Re-Politicization of Religion in Europe: The Next Ten Years. Perspectives on Politics 3: 554-57. [CrossRef]

Klimenko, Anna N., and Vladimir I. Yurtaev. 2018. The 'Moscow as the Third Rome' Concept: Its Nature and Interpretations since the 19th to Early 21st Centuries. Geopolitica(s) 9: 231-51. [CrossRef]

Kratochvil, Petr, and Gaziza Shakhanova. 2020. The Patriotic Turn and Re-Building Russia's Historical Memory: Resisting the West, Leading the Post-Soviet East? Problems of Post-Communism, June 9. [CrossRef] 
Laine, Veera, and Iiris Saarelainen. 2017. Spirituality as a Political Instrument: The Church, the Kremlin, and the Creation of the 'Russian World'. FIIA Working Paper 98, September. Available online: https://researchportal.helsinki.fi/en/publications/spirituality-as-apolitical-instrument-the-church-the-kremlin-and (accessed on 12 January 2022).

Lavrov, Sergei. 2017. Foreign Minister Sergey Lavrov's Remarks at the Security of Christians in the Middle East and Beyond Conference Organised by Foreign Ministers of Russia and Hungary on the Sidelines of the OSCE Ministerial Council Meeting. December 7. Available online: https:/ / www.osce.org/files/f/documents/0/2/362441.pdf (accessed on 27 November 2021).

Lavrov, Sergei. 2019. Stat'ia Ministra inostrannykh del Rossii S.V. Lavrova 'Sosedi po Evrope' Rossiia-ES: Tridtsat' let otnoshenii' dlia 'Rossiiskoi gazety,' 18 dekabria 2019 goda. December 18. Available online: https://www.mid.ru/en/foreign_policy/ news / - / asset_publisher/cKNonkJE02Bw / content/id/3960550?p_p_id=101_INSTANCE_cKNonkJE02Bw\&_101_INSTANCE_ cKNonkJE02Bw_languageId=ru_RU\#sel=5:62:ZmU,5:71:nfg;7:47:Ejh,7:79:amg;8:21:zav,8:32:2pf (accessed on 12 October 2021).

Lavrov, Sergei. 2020. Foreign Minister Sergey Lavrov's Remarks at the Opening of the 28th International Educational Christmas Readings, 'The Great Victory: Heritage and Inheritors'. January 27. Available online: https://m.rusemb.org.uk/article/foreignminister-sergey-lavrovs-remarks-at-the-opening-of-the-28th-international-educational-christmas-readings-the-great-victoryheritage-and-inheritors-moscow-january-27-2020\# (accessed on 27 November 2021).

Lavrov, Sergei V. 2021. On Law, Rights and Rules. Russia in Global Affairs 19: 228-40. [CrossRef]

Lipman, Maria. 2018. Clashing Memory ‘Cultures' in Russia and Europe: An Interview with Alexey Miller. PONARS Eurasia, June 19. Available online: https:/ / www.ponarseurasia.org/clashing-memory-cultures-in-russia-and-europe-an-interview-with-alexeymiller/ (accessed on 2 July 2021).

Lukashevich, Alexander. 2019. Statement by Mr. Alexander Lukashevich, Permanent Representative of the Russian Federation, at the 1221st Meeting of the OSCE Permanent Council. March 28. Available online: https://www.osce.org/files/f/documents/1/b/47 6098.pdf (accessed on 5 June 2021).

Lunkin, R. N. 2018. Tserkov' i vneshniaia politika: Ot 'russkogo mira' k globalizatsii. Aktual'nye Problemy Politologii $45:$ 165-75.

Marsh, Christopher. 2012. Eastern Orthodoxy and the Fusion of National and Spiritual Security. In The Routledge Handbook of Religion and Security. Edited by Chris Seiple, Dennis R. Hoover and Pauletta Otis. New York: Routledge.

Milosevich, Mira. 2020. Russia's Weaponization of Tradition: The Case of the Orthodox Church in Montenegro. CSIS, September 25. Available online: https://www.csis.org/blogs/post-soviet-post/russias-weaponization-tradition-case-orthodox-churchmontenegro (accessed on 21 June 2021).

Mitrofanova, Anastasia V. 2018. Civil Religion and Value Politics in Contemporary Russia. Age of Globalization: Studies in Contemporary Global Processes 4: 136-48.

Mitropolit Volokolamskii Ilarion: Russkaia Pravoslavnaia Tserkov rozhdena v Kieve, a ne v Moskve ili Santkt-Peterburge. 2019. January 14. Available online: http:/ / www.patriarchia.ru/db/text/5353550.html (accessed on 15 May 2021).

Obrashchenie Sviateishego Patriarkha Moskovskogo i vseia Rusi Kirilla k mestobliustiteliu Kievskoi mitropolich'ei kafedry mitropolitu Chernovitskomu i Bukovinskomu Onufriiu, arkhipastyriam, pastyriam i vsem vernym chadam Ukrainskoi Pravoslavnoi Tserkvi v sviazi s situatsiei na Ukraine. 2014. March 2. Available online: http://www.patriarchia.ru/db/text/3588256.html (accessed on 27 November 2021).

Osnovy ucheniia Russkoi Pravoslavnoi Tserkvi o dostoinstve, svobode i pravakh cheloveka. 2008. June 26. Available online: http: / / www.patriarchia.ru/db/text/428616.html (accessed on 12 June 2021).

Østbø, Jardar. 2017. Securitizing 'Spiritual-Moral Values' in Russia. Post-Soviet Affairs 33: 200-16. [CrossRef]

Papkova, Irina. 2011. Russian Orthodox Concordat? Church and State under Medvedev. Nationalities Papers 39: 667-83. [CrossRef]

Paraszczuk, Joanna. 2015a. Lavrov: IS Committing 'Genocide' Against Christians. RFE/RL, March 3. Available online: https: //www.rferl.org/a/russia-genocide-accusation-isis-christians-egypt/26879905.html (accessed on 14 May 2021).

Paraszczuk, Joanna. 2015b. Russia Blames the West after IS Mass Beheading in Libya. RFE/RL. February 17. Available online: https:/ / www.rferl.org/a/islamic-state-egyptian-christians-beheadings-west-russia/26854455.html (accessed on 25 August 2021).

Payne, Daniel P. 2010. Spiritual Security, the Russian Orthodox Church, and the Russian Foreign Ministry: Collaboration or Cooptation? Journal of Church and State 52: 712-27. [CrossRef]

Petro, Nicolai N. 2015. Russia's Orthodox Soft Power. Carnegie Council, March 23. Available online: https:/ /www.carnegiecouncil.org/ publications/articles_papers_reports/727 (accessed on 10 July 2021).

Petro, Nicolai N. 2019. The Russian Orthodox Church. In Russia's Foreign Policy: Change and Continuity in National Identity, 5th ed. Edited by Andrei P. Tsygankov. Lanham: Rowman \& Littlefield, pp. 217-32.

Pieper, Moritz. 2020. Russkiy Mir: The Geopolitics of Russian Compatriots Abroad. Geopolitics 25: 756-79. [CrossRef]

Poe, Marshall T. 1997. 'Moscow, the Third Rome': The Origins and Transformations of a Pivotal Moment. National Council for Soviet and East European Research, October 10. Available online: https:/ / www.ucis.pitt.edu/nceeer/1997-811-25-Poe.pdf (accessed on 23 August 2021).

Ponomariov, Alexander. 2019. Theopolitics on the Grand Chessboard: Ukraine between the Church Canons and the Canons of War. CEES Working Paper 2. September. Available online: https://noek.info/publikationen/1278-cees-working-paper-no-2theopolitics-on-the-grand-chessboard (accessed on 15 November 2021).

Pozdnyayev, Mikhail. 2004. The Strength and Weakness of Orthodoxy. Current Digest of the Post-Soviet Press 55: 19-20. 
Putin, Vladimir. 2012. Poslanie Prezidenta Federal'nomu Sobraniiu. December 12. Available online: http://kremlin.ru/events/ president/news/17118 (accessed on 15 May 2021).

Putin, Vladimir. 2013. Poslanie Prezidenta Federal'nomu Sobraniiu. December 12. Available online: http://kremlin.ru/events/ president/news/19825 (accessed on 15 May 2021).

Putin, Vladimir. 2014a. Poslanie Prezidenta Federal'nomu Sobraniiu. December 4. Available online: http://www.kremlin.ru/events / president/transcripts/messages/47173/videos (accessed on 15 May 2021).

Putin, Vladimir. 2014b. Obrashchenie Prezidenta Rossiiskoi Federatsii. March 18. Available online: http://www.kremlin.ru/events/ president/news/20603 (accessed on 15 May 2021).

Putin, Vladimir. 2021. Stat'ia Vladimira Putina 'Ob istoricheskom edinstve russkikh i ukraintsev'. July 12. Available online: http:/ / kremlin.ru/events/president/news / 66181 (accessed on 15 May 2021).

Putin: Almost All Syrian Territory Freed, Including Historic Christian Regions. 2017. RT, December 4. Available online: https: //www.rt.com/news/411909-syria-freed-terrorists-putin/ (accessed on 27 November 2021).

Riabov, Oleg, and Tatiana Riabova. 2014. The Decline of Gayropa? How Russia Intends to Save the World. Eurozine, February 5. Available online: https:/ / www.eurozine.com/the-decline-of-gayropa/\#footnote-17 (accessed on 12 October 2021).

Rimestad, Sebastian. 2015. The Interaction Between the Moscow Patriarchate and the European Court of Human Rights. Review of Central and East European Law 40: 31-55. [CrossRef]

Russia Inaugurates Cathedral Without Mosaics of Putin, Stalin. 2020. Reuters, June 14. Available online: https://www.reuters.com/ article/us-russia-military-church-idUSKBN23L0K7 (accessed on 12 January 2021).

S.V. Lavrov: MID i Tserkov ob"ediniiaet obshchee ponimanie kliuchevoi roli mezhkonfessional'nogo, mezhtsivilizatsionnogo dialoga. 2011. December 24. Available online: http:/ / www.patriarchia.ru/db/text/1392600.html (accessed on 23 October 2021).

Schmemann, Serge. 1997. Arafat Enters Into a New Fray Over a Russian Church. New York Times, July 11.

Shekhovtsov, Anton. 2018. Russia and the Western Far Right: Tango Noir. New York: Routledge.

Sherr, Dzheims, and Kaarel Kullamaa. 2019. Russkaia Pravoslavnaia Tserkov': Vera, vlast' i zavoevanie. Tallinn: Estonian Foreign Policy Institute, December, Available online: https://icds.ee/ru/russkaja-pravoslavnaja-cerkov-vera-vlast-i-zavoevanija/ (accessed on 12 January 2022).

Shevchenko, Maksim. 2013. My ne Evropa? I slava bogu! MK.RU, February 10. Available online: https://www.mk.ru/politics/2013/0 2/10/810258-myi-ne-evropa-i-slava-bogu.html (accessed on 13 August 2021).

Solik, Martin, and Vladimir Baar. 2019. The Russian Orthodox Church: An Effective Religious Instrument of Russia's 'Soft' Power Abroad. Acta Politologica 11: 13-41.

Solodovnik, Svetlana. 2014. Russia: The Official Church Chooses the State. Russian Social Science Review 55: 55-83. [CrossRef]

Soroka, George. 2016. Putin's Patriarch: Does the Kremlin Control the Church? Foreign Affairs, February 11. Available online: https:/ / www.foreignaffairs.com/articles/russian-federation/2016-02-11/putins-patriarch (accessed on 4 May 2021).

Soroka, George. 2017. Religion and the Making of Post-War Europe: Assessing Historical and Contemporary Perspectives on European Integration. Politics and Religion 10: 906-16. [CrossRef]

Soroka, George. 2018a. Blessings and Curses from Constantinople: How the Orthodox Church is Reshaping the Conflict Between Russia and Ukraine. Foreign Affairs, October 25. Available online: https://www.foreignaffairs.com/articles/ukraine/2018-10-25 /blessings-and-curses-constantinople (accessed on 4 May 2021).

Soroka, George. 2018b. A House Divided: Orthodoxy in Post-Maidan Ukraine. New Eastern Europe XXXI: 90-97.

Soroka, George, and Christopher Rhodes. 2020. An Introduction to Conflict, Politics, and the Christian East: Towards a Theoretical Typology. Religion, State and Society 48: 314-22. [CrossRef]

Statement by the Patriarch's Commission on the Family, Protection of Motherhood and Childhood (Russian Orthodox Church): On the Publication of UNICEF's Position Paper in Support of Legalisation of Same-Sex Union. 2014. December 18. Available online: https:/ / pk-semya.ru/images/phocagallery/news/2014/3/PCF_Position_on_UNICEF_Statement.pdf (accessed on 12 May 2021).

Stoeckl, Kristina. 2016. The Russian Orthodox Church as Moral Norm Entrepreneur. Religion, State E Society 44: 132-51.

Stoeckl, Kristina. 2020a. The Rise of the Russian Christian Right: The Case of the World Congress of Families. Religion, State E Society 48: 223-38.

Stoeckl, Kristina. 2020b. The End of Post-Soviet Religion: Russian Orthodoxy as a National Church. Public Orthodoxy, July 20. Available online: https: / publicorthodoxy.org/2020/07/20/the-end-of-post-soviet-religion/ (accessed on 20 January 2022).

Suslov, M. D. 2015. 'Holy Rus': The Geopolitical Imagination in the Contemporary Russian Orthodox Church. Russian Social Science Review 56: 43-62. [CrossRef]

Suslov, Mikhail. 2018. 'Russian World' Concept: Post-Soviet Geopolitical Ideology and the Logic of 'Spheres of Influence'. Geopolitics 23: 330-53. [CrossRef]

Sviateishii Patriarkh Kirill obratilsia s privetstvennym slovom k uchastnikam VII Vsemirnogo kongressa rossiiskikh sootechestvennikov, prozhivaiushchikh za rubezhom. 2021. October 15. Available online: https://mospat.ru/ru/news/88257/ (accessed on 27 November 2021).

Sviateishii Patriarkh Kirill: 'Russkii mir-Osobaia Tsivilizatsiia, Kotoruiu Neobkhodimo sberech'. 2014. September 8. Available online: http:/ / www.patriarchia.ru/db/text/3730705.html (accessed on 17 July 2021). 
Torbakov, Igor. 2014. The Russian Orthodox Church and Contestations Over History in Contemporary Russia. Demokratizatsiya 22: 145-70.

Tsygankov, Andrei P. 2019. Russia's Foreign Policy: Change and Continuity in National Identity, 5th ed. Lanham: Rowman \& Littlefield.

Tsygankov, Andrei P., and Pavel A. Tsygankov. 2010. National Ideology and IR Theory: Three Incarnations of the 'Russian Idea'. European Journal of International Relations 16: 663-86. [CrossRef]

Valaam: Vladimir Putin o pravoslavii, ommunizme i vere. 2018. Vesti.ru, January 14. Available online: https://www.vesti.ru/ article/1477087\#/video/https\%3A\%2F\%2Fplayer.vgtrk.com\%2Fiframe\%2Fvideo\%2Fid\%2F1750922\%2Fstart_zoom\%2Ftrue\% 2FshowZoomBtn\%2Ffalse\%2Fsid\%2Fvesti\%2FisPlay\%2Ftrue\%2F\%3Facc_video_id\%3D742255 (accessed on 15 May 2021).

Vstupitel'noe slovo Ministra inostrannykh del Rossii S.V. Lavrova na press-konferentsii po itogam X zasedeniia Rabochei gruppy po vzaimodeistviiu MID Rossii i Russkoi Pravoslavnoi Tserkvi, Moskva, 20 noiabria 2007 goda. 2007. November 21. Available online: https:/ / www.mid.ru/en/vistupleniya_ministra/-/asset_publisher/MCZ7HQuMdqBY/content/id/356698?p_p_id= 101_INSTANCE_MCZ7HQuMdqBY\&_101_INSTANCE_MCZ7HQuMdqBY_languageId=ru_RU (accessed on 15 November 2021).

Warner, Gerald. 2013. New Perceptions of Putin. The Scotsman, June 23.

Western Schools Teach Children That Jesus Was Bisexual, Russian Foreign Minister Says. 2021. The Moscow Times, June 29. Available online: https:/ / www.themoscowtimes.com/2021/06/29/western-schools-teach-children-that-jesus-was-bisexual-russianforeign-minister-says-a74365 (accessed on 27 January 2022).

Wołowski, Paweł. 2010. Patriarch Kirill in Ukraine: The Servant of God in the Service of Politics. OSW, August 4. Available online: https://www.osw.waw.pl/en/publikacje/analyses/2010-08-04/patriarch-kirill-ukraine-servant-god-service-politics (accessed on 14 July 2021).

Zamestitel' predsedatelia OVTsS: 'russkii mir—eto tsivilizatsionnaia obshchnost', obrazovannaia obshchimi tsennostiami i obshchim opytom obshchestvennogo stroitel'stva. 2010. June 17. Available online: http://www.patriarchia.ru/db/print/26208.html (accessed on 12 October 2021).

Zarakhovich, Yuri. 2007. Putin's Reunited Russian Church. Time.com, May 17. Available online: http://content.time.com/time/world/ article/0,8599,1622544,00.html (accessed on 27 November 2021).

'Ob osnovakh sotsial'noi kontseptsii Russkoi Pravoslavnoi Tserkvi'. Doklad predsedatelia Otdela vneshnikh tserkovnykh snoshenii mitropolita Smolenskogo i Kaliningradskogo Kirilla. 2008. June 9. Available online: http://www.patriarchia.ru/db/text/422562 .html (accessed on 13 September 2021).

Bol'shaia press-konferentsiia Vladimira Putina. 2018. December 20. Available online: http://www.kremlin.ru/events/president/ news/59455/videos (accessed on 12 October 2021).

Brifing ofitsial'nogo predstavitelia MID Rossii M.V. Zakharovoi. 2019. December 18. Available online: https://archive.mid.ru/ en/web/guest/foreign_policy/news/- / asset_publisher/cKNonkJE02Bw / content/id/3961456?p_p_id=101_INSTANCE_ cKNonkJE02Bw\&_101_INSTANCE_cKNonkJE02Bw_languageId=ru_RU\#21 (accessed on 12 October 2021).

Deklaratsiia o pravakh i dostoinstve cheloveka X Vsemirnogo Russkogo Narodnogo Sobora. 2006. April 6. Available online: http: / / www.patriarchia.ru/db/text/103235.html (accessed on 12 January 2022).

Doklad Sviateishego Patriarkha Kirilla na X Assamblee Fonda 'Russkii mir'. 2016. November 3. Available online: http://www. patriarchia.ru/db/text/4658869.html (accessed on 15 November 2021).

Doverie Institutam. 2020. Levada Center, September 21. Available online: https://www.levada.ru/2020/09/21/doverie-institutam/ (accessed on 17 November 2021).

Iarovaia: Popytki sopriazheniia tekstov pisanii s ekstremizmom nedopustimy. 2015. RIA Novosti, October 15. Available online: https: / / ria.ru/20151015/1302289898.html\#ixzz41wJO0PTj (accessed on 15 August 2021).

Inside Moscow's New Military Megachurch. 2020. RFE/RL. April 28. Available online: https://www.rferl.org/a/inside-moscowsnew-military-megachurch/30580784.html (accessed on 15 November 2021).

Interv'iu Ministra inostrannykh del Rossiiskoi Federatsii S.V Lavrova telekanalu 'Rossiia 24' po sluchaiu 55-letiia mitropolita Ilariona. 2021. July 24. Available online: https://archive.mid.ru/en/foreign_policy/news/-/asset_publisher/cKNonkJE02Bw/content/ id/4830576?p_p_id=101_INSTANCE_cKNonkJE02Bw\&_101_INSTANCE_cKNonkJE02Bw_languageId=ru_RU (accessed on 12 August 2021).

Interv'iu Sviateishego Patriarkha Kirilla predstaviteliam ukrainskikh SMI v preddverii Pervosviatitel'skogo poseshcheniia Ukrainy. 2009. July 24. Available online: http:/ / www.patriarchia.ru/db/text/702122.html (accessed on 21 October 2021).

Interv'iu Sviatieshego Patriarkha Moskovskogo i vseia Rusi Kirilla Pervomu telekanalu. 2010. January 31. Available online: http: / / www.patriarchia.ru/db/text/1058792.html (accessed on 15 November 2021).

Kirill [Gundiaev]. 2000. Norma very kak norma zhizni: Problema sootnosheniia mezhdu traditsionnymi i liberal'nymi tsennostiami v vybore lichnosti i obshchestva. Tserkov i mir 2: 203-21.

Kontseptsiia national'noi bezopasnosti Rossiiskoi Federatsii. 1997. Available online: https://yeltsin.ru/archive/act/39691/ (accessed on 15 May 2021).

Kontseptsiia national'noi bezopasnosti Rossiiskoi Federatsii. 2000. Available online: http:/ / www.kremlin.ru/acts/bank/14927/page/1 (accessed on 15 May 2021).

Kontseptsiia vneshnei politiki Rossiiskoi Federatsii. 2016. Available online: https://www.mid.ru/en/foreign_policy/official_ documents/- / asset_publisher/CptICkB6BZ29/content/id/2542248?p_p_id=101_INSTANCE_CptICkB6BZ29\&_101_INSTANCE_ CptICkB6BZ29_languageId=ru_RU (accessed on 15 May 2021). 
Lavrov: Imperial Orthodox Palestine Society is Important Tool for Positions in Region. 2016. TASS, July 25. Available online: https: / / tass.com/politics/890368 (accessed on 27 November 2021).

Lavrov: Patriarkh Varfolomei po ukazke SShA pytaetsia pokhoronit' vliianie pravoslaviia v mire. 2021. TASS, January 18. Available online: https:/ / tass.ru/obschestvo/10484649 (accessed on 12 January 2022).

Lavrov: Priznaniem PTsU SShA prodvigaiut raskol vo vsem pravoslavnom mire. 2019. Gazeta.ru, November 6. Available online: https:/ / www.gazeta.ru/social/news/2019/11/06/n_13663970.shtml (accessed on 3 August 2021).

Lavrov: US backs Patriarch Bartholomew's Provocation Against Orthodox Church in Ukraine. 2018. TASS, October 12. Available online: https:/ / tass.com/politics/1025791 (accessed on 15 May 2021).

Mitropolit Ilarion: Prevrashchenie Sviatoi Sofii v mechet' v segodniashnikh usloviiakh stalo by nedopustimym narusheniem svobody veroispovedaniia. 2020. June 4. Available online: https:/ / mospat.ru/ru/news/45499/ (accessed on 27 November 2021).

Mitropolit Volokolamskii Ilarion. 2021. Deiatel'nost' OBTsS Mozhno Sravnit' so Slyzheniem Pogranichnikov. May 20. Available online: http:/ / www.patriarchia.ru/db/text/5811777.html (accessed on 12 August 2021).

Mitropolit Volokolamskii Ilarion. 2015. Vozmozhnost' Provedeniia Vsepravoslavnogo Sobora Vyzyvaet Somnenie. December 31. Available online: http:/ / www.patriarchia.ru/db/text/4313597.html (accessed on 15 May 2021).

Montenegro Lawmakers Change Religious Law Opposed by Church. 2020. Associated Press. December 29. Available online: https: / /apnews.com/article/montenegro-europe-serbia-laws-7e66d729c7e9f33eb56bf20ac2e74d00 (accessed on 27 January 2022).

O gosudarstvennoi politike Rossiiskoi Federatsii v otnoshenii sootechestvennikov za rubezhom. 2010. Available online: http: / / pravo.gov.ru/proxy/ips / ?docbody=\&firstDoc=1\&lastDoc=1\&nd=102059861 (accessed on 12 November 2021). First published in 1999.

Obrashchenie Sviateishego Patriarkha Kirilla k polnote Russkoi Pravoslavnoi Tserkvi. 2014. June 17. Available online: http:/ /www. patriarchia.ru/db/text/3675015.html (accessed on 25 October 2021).

Osnovy sotsial'noi kontsepstii Russkoi Pravoslavnoi Tserkvi. 2000. Available online: http://www.patriarchia.ru/db/text/419128.html (accessed on 15 May 2021).

Otvety Sviateishego Patriarkha Kirilla na vstreche s molodezh'iu na II Mezhdunarodnom pravoslavnom studencheskom forume. 2016. October 14. Available online: http:/ / www.patriarchia.ru/db/text/4640062.html (accessed on 12 June 2021).

Patriarch Kirill Proposes Adding Reference to God to Russian Constitution. 2020. Orthodox Christianity, February 3. Available online: https: / / orthochristian.com/127683.html (accessed on 27 November 2021).

Patriarkh Aleksii II: Zapad Tselenapravlenno Rastlevaet Rossiian. 2000. December 15. Available online: https://lenta.ru/news/2000/1 2/15/aleksyi/ (accessed on 12 October 2021).

Patriarkh Kirill nazval chislo dukhovenstva i khramov RPTs. 2017. RIA Novosti, November 29. Available online: https:/ / ria.ru/201711 29/1509815167.html (accessed on 23 September 2021).

Patriarkh Kirill vstretilsia s predstoiatelem Assiriiskoi Tserkvi Vostoka. 2014. Pravoslavie.ru, May 29. Available online: https: / / pravoslavie.ru/71082.html (accessed on 12 January 2022).

Patriarkh prizval ne politizirovat' poniatie 'russkii mir'. 2015. RIA Novosti, July 20. Available online: https://ria.ru/20150720/1137980 877.html (accessed on 15 May 2021).

Patriarshee i Sinodal'noe poslanie v sviazi s sityatsiei v Chernogorii. 2019. December 30. Available online: http:/ /www.patriarchia.ru/ $\mathrm{db} /$ print/5555471.html (accessed on 15 November 2021).

Pompeo Tells of U.S. Help for Ukraine Church to Escape Russian Influence. 2021. UNIAN, January 4. Available online: https: / / www.unian.info/politics/orthodoxy-pompeo-tells-of-u-s-help-for-ocu-to-rid-russia-influence-11275526.html (accessed on 15 May 2021).

Popravki v Konstitutsiiu RF-2020 s kommentariami. 2020. June 18. Available online: https://mr-rf.ru/articles/society/81878popravki-v-konstitutsiyu-rf-2020-s-kommentariyami/ (accessed on 27 November 2021).

Pushkov: Posle dogovora s ES vmesto paradov Pobedy v Kieve nachnutsia gei-parady. 2013. Vzgliad, November 7. Available online: https://vz.ru/news/2013/11/7/658568.html (accessed on 12 August 2021).

Putin obsudil s Sovbezom polozhenie Russkoi Tserkvi na Ukraine. 2018. Rossiiskaia gazeta, October 12. Available online: https: //rg.ru/2018/10/12/putin-obsudil-s-sovbezom-polozhenie-russkoj-cerkvi-na-ukraine.html (accessed on 15 November 2021).

Putin: Rossiia-pravoslavnaia derzhava. 2005. Grani.ru. September 9. Available online: https://graniru.org/Society/Religion/m.9477 4.html (accessed on 21 October 2021).

Religious Belief and National Belonging in Central and Eastern Europe. 2017. Pew Research Center, May 10. Available online: https:/ / www.pewforum.org/2017/05/10/religious-belief-and-national-belonging-in-central-and-eastern-europe/ (accessed on 17 June 2021).

Russia to Continue Providing Assistance to Christians in the Middle East_Lavrov. 2019. TASS, May 20. Available online: https: / / tass.com/society/1059167 (accessed on 17 November 2021).

Russian Church Leader Defends Moscow's Bombing Campaign in Syria. 2016. RFE/RL, January 7. Available online: https://www.rferl. org/a/russia-church-leader-defends-syria-war/27473825.html (accessed on 15 May 2021).

Russian Mosaic Featuring Putin Won't Be Displayed in New Armed Forces Cathedral. 2020. RFE/RL, May 1. Available online: https:/ / www.rferl.org/a/russian-mosaic-featuring-putin-won-t-be-displayed-in-new-armed-forces-cathedral/30587795.html (accessed on 12 January 2022). 
Russian Orthodox Church Says 'No' to Stalin's Mosaic in the New Temple of the Russian Armed Forces. 2020. Orthodox Times, May 13. Available online: https:/ / orthodoxtimes.com/russian-orthodox-church-says-no-to-stalins-mosaic-in-the-new-temple-of-therussian-armed-forces/ (accessed on 12 January 2022).

Slovo Sviateishego Patriarkha Kirilla na torzhestvennom akte vo Dvortse Respubliki Minska. 2009. September 26. Available online: http:/ / www.patriarchia.ru/db/text/750891.html (accessed on 4 August 2021).

Sostoialas' bratskaia beseda Predstoiatelei Russkoi i Bolgarskoi Pravoslavnykh Tserkvei. 2014. May 27. Available online: https: // mospat.ru/ru/news/51444/ (accessed on 12 January 2022).

Sovmestnoe zaiavlenie Papy Rimskogo Frantsiska i Sviateishego Patriarkha Kirilla. 2016. February 12. Available online: http: / / www.patriarchia.ru/db/text/4372074.html (accessed on 15 October 2021).

Stenograficheskii otchet o press-konferentsii dlia rossiiskikh i inostrannykh zhurnalistov. 2007. February 1. Available online: http:/ / www.kremlin.ru/events/president/transcripts/24026 (accessed on 15 May 2021).

Strategiia natsional'noi bezopasnosti Rossiiskoi Federatsii do 2020 goda. 2009. Available online: http:/ /www.kremlin.ru/supplement/ 424 (accessed on 4 November 2021).

Strategiia natsional'noi bezopasnosti Rossiiskoi Federatsii. 2015. Available online: http://static.kremlin.ru/media/acts/files/00012015 12310038.pdf (accessed on 4 November 2021).

Strategiia natsional'noi bezopasnosti Rossiiskoi Federatsii. 2021. Available online: http:/ / publication.pravo.gov.ru/Document/View/ 0001202107030001 ? index=1\&rangeSize $=1$ (accessed on 4 November 2021).

Sviateishii Patriarkh Kirill vystupil so slovom na Sobranii Predstoiatelei Pomestnykh Pravoslavnykh Tserkvei. 2016. January 22. Available online: https:/ / mospat.ru/ru/news/49855/ (accessed on 12 October 2021).

Tserkov i voina: Osnovy sotsial'noi kontseptsii RPTs ob otnoshenii k sovremennym voinam. 2015. Rublev.com. September 30. Available online: http:/ / rublev.com/novosti/tserkov-i-voina-osnovy-sotsialnoi-kontseptsii-rpts-ob-otnoshenii-k-sovremennym-voinam (accessed on 14 May 2021).

V Moskve predstavili novuiu knigu Sviateishego Patriarkha Kirilla ‘Dialog s istoriei'. 2019. May 21. Available online: http://www. patriarchia.ru/db/text/5438419.html (accessed on 3 June 2021).

V Rossii vozmozhno vse. 2015. Gazeta.ru. April 28. Available online: https://www.gazeta.ru/business/2015/04/27/6658513.shtml (accessed on 9 August 2021).

V Russkoi Pravoslavnoi Tserkvi sozdan Sekretariat Moskovskoi Patriarkhii po zarubezhnym uchrezhdeniiam. 2009. March 31. Available online: http:/ / www.patriarchia.ru/db/text/600982.html (accessed on 7 November 2021).

Vlasti Chernogorii presleduiut Pravoslavnuiu Tserkov po ukrainskomu stsenariiu. 2020. May 25. Available online: http://www. patriarchia.ru/db/text/5641527.html (accessed on 22 August 2021).

Vystuplenie i diskussiia na Miunkhenskoi konferentsii. 2007. February 10. Available online: http://www.kremlin.ru/events/ president/transcripts/24034 (accessed on 23 November 2021).

Vystuplenie Sviateishego Patriarkha Kirilla na torzhestvennom otkrytii III Assamblei Russkogo mira. 2009. November 3. Available online: http:/ / www.patriarchia.ru/db/print/928446.html (accessed on 7 June 2021).

Zasedanie mezhdunarodnogo diskussionnogo kluba 'Valdai'. 2013. September 19. Available online: http://kremlin.ru/events/ president/news/19243/videos (accessed on 24 April 2021).

Zhurnaly zasedaniia Sviashchennogo Sinoda Russkoi Pravoslavnoi Tserkvi. 2009. March 31. Available online: http://www.patriarchia. $\mathrm{ru} / \mathrm{db}$ / text/600732.html (accessed on 13 June 2021). 